\title{
THE DISCOURSE MOTIVATION FOR SPLIT-ERGATIVE ALIGNMENT IN DUTCH NOMINALISATIONS (AND ELSEWHERE)
}

\author{
Freek Van de Velde
}

\begin{abstract}
Dutch nominalisations of the type het eten van vlees ('the eating of meat') have ergative alignment. The alignment is functionally motivated, in that it is a natural consequence of the flow of discourse. The functional account that is put forward here draws on the notion of Preferred Argument Structure (Du Bois 1987) and on the distinction between foregrounded and backgrounded discourse (Hopper \& Thompson 1980). Support for this account comes from other domains of ergativity in Dutch, such as causativised predicates and participial constructions and from the observation that the alignment in Dutch nominalisations is in fact split-ergative. The present study adduces corpus evidence to corroborate the claims. In the last section, the analysis is cast in a Functional Discourse Grammar model (Hengeveld \& Mackenzie 2008), including its hitherto underdescribed Contextual Component.
\end{abstract}

Keywords: Nominalisation; Ergativity; Split-ergativity; Alignment; Dutch; Functional Discourse Grammar.

\section{Introduction}

This article is concerned with argument realisation in Dutch nominalisations. ${ }^{1}$ As shown in Section 2, the argument realisation is basically ergative in a double sense: Both the expression of the arguments and the marking of the arguments follow an ergative pattern. The ergative alignment is not pure, however. Argument realisation in Dutch nominalisations shows ergative splits along different dimensions, both in terms of its expression and in terms of its marking. In Section 3, a pragmatic explanation is offered for this split-ergative pattern, which is argued to be the result of the backgrounding function of nominalisations, the flow of information and the presuppositional import. Support for this account comes from other domains in Dutch syntax where we find ergative patterning. In Section 4, the use of nominalisations and their argument

${ }^{1}$ I would like to thank the editors of this special issue and the participants of the IW-FDG-2011 workshop in Barcelona for helpful comments - without implicating them in remaining errors, though. This study has been made possible by the financial support of the Flanders Research Foundation (FWO). 
realisation will be analysed in the framework of Functional Discourse Grammar (FDG) (Hengeveld \& Mackenzie 2008, 2010). In order to account for the expression of nominalisations, we need to acknowledge the central role of the Contextual Component.

\section{Argument realisation in Dutch nominalisations}

Dutch nominalisations come in various sorts. As argued in Dik (1985) they form a cline from more verbal to increasingly more nominal. ${ }^{2}$ A similar cline, though with more elaborate distinctions, can be found in English (see Mackenzie 1985; Mackenzie 1996: 326-328, referring to Ross 1973).

$$
\begin{aligned}
& \text { Het is ongehoord dat mensen } \\
& \text { it is outrageous that people } \\
& \text { 'It is outrageous that people slaughter animals.' }
\end{aligned}
$$

\begin{tabular}{|c|c|c|c|c|c|}
\hline $\begin{array}{l}\text { Het } \\
\text { the }\end{array}$ & $\begin{array}{l}\text { slachten } \\
\text { slaughtering }\end{array}$ & $\begin{array}{l}\text { van } \\
\text { of }\end{array}$ & $\begin{array}{l}\text { dieren } \\
\text { animals }\end{array}$ & & $\begin{array}{l}\text { ongehoord. } \\
\text { outrageous }\end{array}$ \\
\hline \multicolumn{6}{|c|}{ 'The slaughtering of animals is outrageous.' } \\
\hline e & $\begin{array}{l}\text { slacht } \\
\text { slaughter }\end{array}$ & $\begin{array}{l}\text { van } \\
\text { of }\end{array}$ & $\begin{array}{l}\text { dieren } \\
\text { animals }\end{array}$ & & $\begin{array}{l}\text { ongehoord. } \\
\text { outrageous }\end{array}$ \\
\hline
\end{tabular}

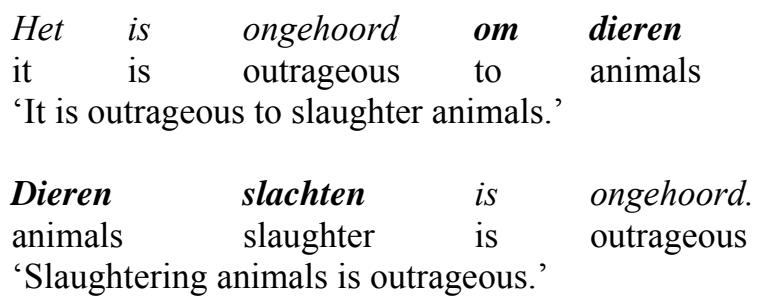

'The slaughter of animals is outrageous.'

In this article, the focus will be on nominalisations of the type under (4). The defining characteristics of this type are that they are productively derived from the verbal root and they can be used with determiners.

The argument realisation in Dutch nominalisations follows an ergative pattern ('Ergative-Possessive' in the classification by Koptjevskaja-Tamm 1993, 2003; see also Alexiadou 2001 on cognate languages): The argument encoded as a possessive phrase is either the single argument of an intransitive predication $(\mathrm{S})$, or the undergoer argument of a transitive predication (U). This is illustrated in (6)-(7). In (6), the possessive van adpositional phrase encodes the actor of the intransitive niezen ('sneeze'). In (7), the

\footnotetext{
${ }^{2}$ It could be argued that there is an additional type of nominalisation, in which the argument is realised as an adjective: Dierlijke slacht (animal-ADJ slaughter). I consider this as a subtype of (5). In this paper I also ignore constructions in which the verbal noun, often in the form of a participle, is used as a dependent of the argument, as in Geslachte dieren zijn ongehoord ('Slaughtered animals are outrageous'), which sometimes carries the same meaning as nominalisations: De gevolgen van de instortende huizenmarkt (Google) ('the consequences of the collapsing real estate market') and de gevolgen van het instorten van de huizenmarkt (Google) ('the consequences of the collapse of the real estate market'), can be used interchangeably, although there is an aspectual difference. Furthermore, nominalisations built with derivational suffixes such as -ing, -age, -erij or nominalisations with the prefix ge- are not treated here either.
} 
possessive van adpositional phrase encodes the undergoer argument of the transitive verb achterlaten ('leave behind') and the actor is encoded as a door ('by') adpositional phrase, which in main clauses is used for the actor in passive clauses. ${ }^{3}$



Nominalisations like (7), in which both the actor and the undergoer are expressed are rare in Dutch, as well as in other languages. Nominalisations typically undergo what Mackenzie has called 'valency reduction' (Mackenzie 1985, 1996: 336-342). It is fairly common to encounter nominalisations of intransitive verbs (and occasionally of transitive verbs as well) without any arguments being overtly expressed, see (8).

$\begin{array}{lllllll}\text { Bij het niezen } & \text { is het vrijwel } & \text { onmogelijk } & \text { om } \\ \text { during the sneezing is it virtually } & \text { impossible } & \text { to } \\ \text { de ogen open te houden. (Google) } & & \\ \text { the eyes open to keep } \\ \text { 'It is virtually impossible to keep your eyes open while sneezing.' }\end{array}$

For transitive verbs, expression of both the actor and the undergoer is much rarer than the expression of just one of the arguments. Hopper \& Thompson (1980: 285) tallied five nominalisations with two arguments in a sample of 100 English nominalisations and Dik (1985: 104) only ran across one instance in his 100 instances sample of Dutch nominalisations. The most common case is for the undergoer argument to be expressed, as in (9), where the possessive adpositional phrase van de woning encodes the undergoer argument of the transitive predicate achterlaten ('leave behind'). Expression of the actor argument alone also occurs, but is far less frequent. In Dik's (1985: 104) count, this occurred in just one out of 100 nominalisations. The expression of the actor argument in the absence of the undergoer argument can either take the form of a possessive van adpositional phrase, or a door adpositional phrase; see (10) and (11), respectively. $^{4}$

(9) richtlijnen voor het achterlaten van de
$\begin{aligned} & \text { Beknopte woning } \\ & \text { (Google) } \\ & \text { basic guidelines for the leaving }\end{aligned}$ of the house
'Basic guidelines for leaving the house'

\footnotetext{
${ }^{3}$ A complication is that the door adpositional phrase can also be used to encode the $\mathrm{S}$ argument: Het niezen door baby's, though the result sounds less natural than the variant with the van adpositional phrase, and examples are much harder to find on the internet or in a text corpus.

${ }^{4}$ Note that Dutch nafluiten is unequivocally transitive, as opposed to English wolf-whistle.
} 


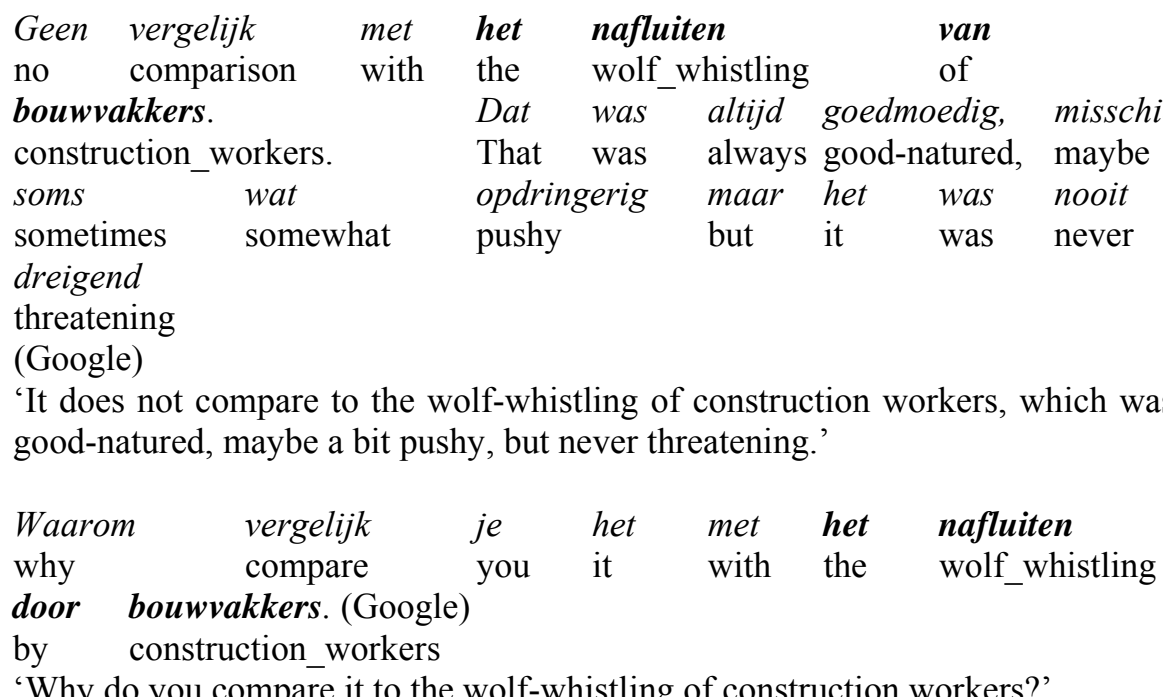

Since the possessor van adpositional phrase in nominalisations of transitive predicates can express either the undergoer, as in (9), or the actor, as in (10), expression of a single argument can create ambiguity. Taken in isolation, the argument van je buurman in (12) can be an undergoer or an actor. In most cases, this ambiguity is resolved by two factors, the context ${ }^{5}$ and the rule that the possessor van adpositional phrase encodes the undergoer by default. In (10), we know that construction workers are more likely to wolf-whistle at women than to be wolf-whistled at themselves, suggesting that the default reading of van bouwvakkers as the undergoer argument is inappropriate here. In (12), the context does not provide an immediate clue - anyone's neighbour is probably equally likely to murder than to be murdered - in which case we fall back on the default reading of the neighbour as the undergoer argument.

$$
\begin{aligned}
& \text { het vermoorden van je buurman } \\
& \text { the murdering of your neighbour } \\
& \text { 'the murdering of your neighbour' }
\end{aligned}
$$

This means that Dutch nominalisations are ergative in a double sense: First, the marking of the arguments (van vs. door adpositional phrase) follows a basically ergative pattern. Second, the expression of the arguments is also ergatively motivated: In the default case where the nominalisation carries only one argument with it, it is normally either the single argument of the intransitive or the undergoer argument of the transitive predicate.

This double ergative tendency is not entirely clear-cut, however. As pointed out, the actor can be encoded as a possessive van adpositional phrase too, as in (10). But there are other constructions as well that confound the ergative system of Dutch nominalisations. The ergative alignment in the expression of the arguments shows a split along the nominal-pronominal dimension, such that pronouns are more likely to follow accusative alignment, a cross-linguistically not uncommon split (see Silverstein 1986; Dixon 1994: 83ff.). This is shown in (13)-(20). In nominalisations of intransitive verbs, both the non-pronominal argument (die kinderen) and the pronominal argument

\footnotetext{
${ }^{5}$ In this sense, context is taken as a broad notion, comparable to what Connolly (2007: 15-17) calls the broader socio-cultural situational context. See further below, Section 4 .
} 
(jou) express the S argument, as in (13) and (15), respectively. In nominalisations of transitive verbs the single argument is typically interpreted as $U$, as noted above, but an interpretation as $\mathrm{A}$ is also possible. This interpretation shift is much easier with pronouns than with lexical NPs. In (14) the non-pronominal argument (kinderen) is typically interpreted as U. To be sure, the default reading can easily be overridden by contextual factors, as was already made clear in (10). ${ }^{6}$ Adding grote ('big') in (14) would increase the likelihood of an actor reading for the nominalisation argument, as we know that big boys are more likely to be the bullies than the victims. With the pronoun, the role of the context is less strong. In fact, the A interpretation could be argued to be the default reading. The A reading of the pronoun jou in (16) is not coerced by the context. In the absence of contextual clues, the nominalisation in (19) is more naturally interpreted as expressing the A argument than the nominalisation in (20). ${ }^{7}$ The ergativeaccusative split concerns not only the expression of the arguments, but also their marking. Normally, the undergoer takes priority over the actor for the possessive marking when both arguments are simultaneously expressed, but when the actor is a pronoun, Dutch nominalisations allow double possessive constructions (see (17)), although the ergative pattern with the actor encoded as a door adpositional phrase is still possible (see (18)). Crucially, however, the semantic roles in (17) cannot be interpreted the other way around, not even when the context would trigger such an interpretation (?'dat pesten van kinderen (A) van jou (U)). This is also partly due to the clustering of the $\mathrm{U}$ argument and the verb, as indicated by their linear contiguity and by the indefiniteness of the $U$ argument, but note that even without this clustering word order and with a definite $\mathrm{U}$ argument, the difference between the semantic roles obtains (dat pesten van jou $(\mathrm{A})$ van die kinderen $(\mathrm{U}) /{ }^{? ?}$ dat pesten van jou $(\mathrm{U})$ van die kinderen $(\mathrm{A})$ ).

$$
\begin{aligned}
& \text { Dat gillen van die kinderen (S) moet ophouden. } \\
& \text { that squealing of those children must stop }
\end{aligned}
$$

'That squealing of those children must stop'

$\begin{array}{lll}\begin{array}{l}\text { Dat pesten van kinderen (normally interpreted as U) } \\ \text { that bullying of of children }\end{array} & \begin{array}{l}\text { moet } \\ \text { must }\end{array} \\ \text { ophouden } & \\ \text { stop } & & \\ \text { 'That bullying of children must stop' } & \end{array}$



'That squealing of yours must stop'

Dat pesten van jou (easily interpreted as A) moet ophouden.

\footnotetext{
${ }^{6}$ In fact, definiteness also plays a role in desambiguting the semantic roles. If we use a definite determiner in (14), die kinderen ('those children'), the A reading becomes more plausible. What we see here is a gradual split along the givenness hierarchy (see Gundel et al. 1993), or topicality hierarchy (a cover term for several related hierarchies, see Siewierska 2004: 149), rather than a strict pronominal vs. nominal split.

${ }^{7}$ Examples like (16) are not easy to find, as the non-expression of the undergoer argument of a transitive verb is often pragmatically infelicitous $\left({ }^{? ?} \mathrm{He}\right.$ destroys $\left.\varnothing\right)$. One context in which it does occur is when the verb has a habitual meaning, e.g. He drinks, but an habitual meaning is often at odds with the telic aspect of many transitive verbs.
} 
that bullying of you must stop

'That bullying of yours must stop'

$\begin{array}{llllll}\text { Dat } & \text { pesten } & \text { van } & \text { kinderen (U) } & \text { van } & \text { jou (A) moet ophouden. } \\ \text { that bullying } & \text { of } & \text { children } & \text { of } & \text { you must stop }\end{array}$

'That bullying of children of yours must stop'

$\begin{array}{llllll}\text { Dat pesten } & \text { van } & \text { kinderen }(\mathrm{U}) & \text { door } & \text { jou }(\mathrm{A}) \text { moet } & \text { ophouden. } \\ \text { that bullying } & \text { of } & \text { children } & \text { by } & \text { you must } & \text { stop }\end{array}$

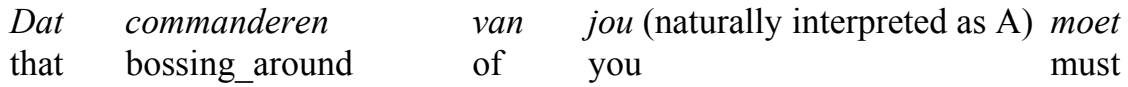
ophouden.

stop

'That bossing around of yours must stop'

$\begin{array}{lll}\text { Dat commanderen } & \text { van collega's (naturally interpreted as U) } & \text { moet } \\ \text { that bossing_around } & \text { of colleagues } & \text { must } \\ \text { ophouden. } & & \\ \text { stop } & & \\ \text { 'That bossing around of colleagues must stop' }\end{array}$

Apart from the nominal-pronominal divide, there are other, more intricate splits at play. One other factor that influences alignment is the distinction between premodification and postmodification. Possessors in Dutch can be postmodifiers of the noun, as in (21), where they take the form of a van adpositional phrase, or they can be premodifiers of the noun, as in (22) and (23). In (22), the possessor is marked by the suffix (or clitic) $-s$, and in (23) we have the 'resumptive pronoun possessor' (also called the 'prenominal periphrastic possessive'), which occurs in many other Germanic languages as well (see Harbert 2007: 158-161). There are constraints on what kind of elements can be used in construction (22) and construction (23). Apart from pronouns, proper names, and close appositions with proper names, both constructions only allow kinship terms and some professions, which may be preceded by a possessive pronoun. The cut-off point is not entirely clear, and language users differ on how tolerant they are with regard to the internal syntax of the possessors in these constructions. In general, the construction in (23) is considerably more flexible: Possessors can be used with other determiners than just the possessive pronoun, for instance, and animals are also allowed as possessors. ${ }^{8}$ The exact delineation, however, is not at issue here; for details, the reader is referred to Haeseryn et al. (1997: 294-295, 821).

de fiets van mijn vader
the bicycle of my father

'the bicycle of my father'

$$
\begin{array}{lll}
\text { mijn vader-s } & \text { fiets } \\
\text { my father's } & \text { bicycle } \\
\text { 'my father's bicycle' } &
\end{array}
$$

${ }^{8}$ Evelien Keizer draws my attention to examples with a personal pronoun: hem z'n fiets (literally: 'him his bike'). 


$$
\begin{array}{lll}
\text { mijn vader z'n } & \text { fiets } \\
\text { my father his } & \text { bicycle } \\
\text { 'my father's bicycle' } &
\end{array}
$$

If the internal syntax of the arguments in a nominalisation conforms to the syntactic constraints on constructions like (21)-(23), the arguments can be encoded as premodifying possessors. Such premodifying possessor arguments (and a fortiori possessive pronouns), have an inclination towards accusative alignment in their expression. This is illustrated in (24)-(26). Expression of the single argument can take the form of a premodifying possessor, as in (24). If only one of the arguments of a transitive predicate is expressed as a premodifying possessor, the default will be to express the actor, rather than the undergoer. Compare (24)-(25) with the postmodifying possessor in (26). The premodifying possessor can only be interpreted as the actor (see Haeseryn et al. 1997: 883), whereas the postmodifier is preferably interpreted as the undergoer, although in the right context it can also be read as the actor (see above). ${ }^{9}$

$\begin{array}{lll}\text { koning } & \text { Alberts (S) } & \text { aftreden } \\ \text { king } & \text { Albert's } & \text { abdication }\end{array}$

'king Albert's abdication'

Pauls $(\mathrm{A} /$ ?? $\mathrm{U})$
tegenwerken is
Paul's counteracting is niet goed voor de
op kantoor
at office
'Paul's counteracting is not good for the atmosphere at the office'

Dat tegenwerken van Paul (U/A) is niet goed voor de
that counteracting of Paul is not good for the
sfeer op kantoor
atmosphere at office
'This counteracting of Paul is not good for the atmosphere at the office'

The two alignment splits - the pronominal split and the positional split - are not entirely independent from each other. As both pronouns and the elements that are allowed in the premodifying possessor constructions are high on the topicality hierarchy, one could argue that the two splits boil down to one referentiality split (see Koptjevskaja-Tamm 2003: 740). Still, the premodifying possessors are accusatively aligned even if the postmodifying possessor ranks higher on the topicality hierarchy, suggesting that at least in Dutch, the two factors are not interchangeable: If the alignment was just split along the referentiality hierarchy, then (27) would be ruled out, as the personal pronoun mij ('me') would be interpreted as the A role.

$\begin{array}{lllll}\text { Jans (A) } & \begin{array}{l}\text { onophoudelijke } \\ \text { incessant }\end{array} & \begin{array}{l}\text { tegenwerken } \\ \text { counteracting }\end{array} & \begin{array}{l}\text { mij (U) } \\ \text { John's }\end{array} \\ \text { 'John's incessant counteracting of me' } & & & \end{array}$

${ }^{9}$ In (25), a nominalisation like tegenwerking would be more natural, but the infinitival nominalisation is not ungrammatical. 


\section{Freek Van de Velde}

The ergative tendency is confirmed by a corpus study on 500 nominalisations in the Dutch newspaper NRC (issues from 2005), included in the Twente News Corpus (TwNC). ${ }^{10}$ The query included nominalisations consisting of a definite article or a demonstrative pronoun, a nominalisation in -en, followed by a van adpositional phrase or a door adpositional phrase. In this way, only nominalisations with at least one argument expressed in an adpositional phrase were selected. On the basis of these results, it is impossible to say what the proportion is of nominalisations without any arguments at all, but we do get an idea of which arguments are preferred when arguments are expressed.

In terms of expression of arguments, Figure 1 shows that in all nominalisations where only one argument is expressed (435 out of the total of 500 nominalisations, so the overwhelming majority of the cases), this argument is either the $\mathrm{S}$ or the $\mathrm{U}$ argument.

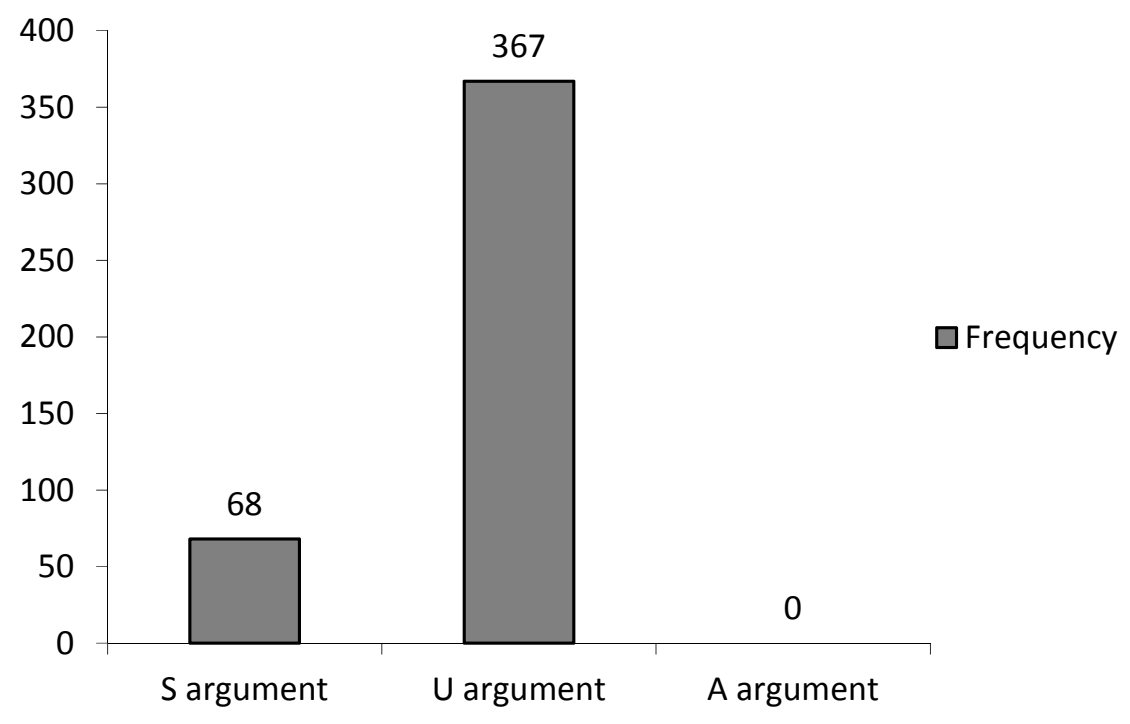

Figure 1: One-argument nominalisations

If we look at the nominalisations that have 'inherited' other arguments or modifiers as well, besides their S, U or A arguments (57 out of the total of 500 nominalisations), a similar ergative tendency emerges, see Figure 2.

\footnotetext{
${ }^{10}$ The TwNC is a $>300,000,000$ token corpus of early $21^{\text {st }}$ century Dutch newspaper texts, see http://wwwhome.cs.utwente.nl/ druid/TwNC/TwNC-main.html.
} 


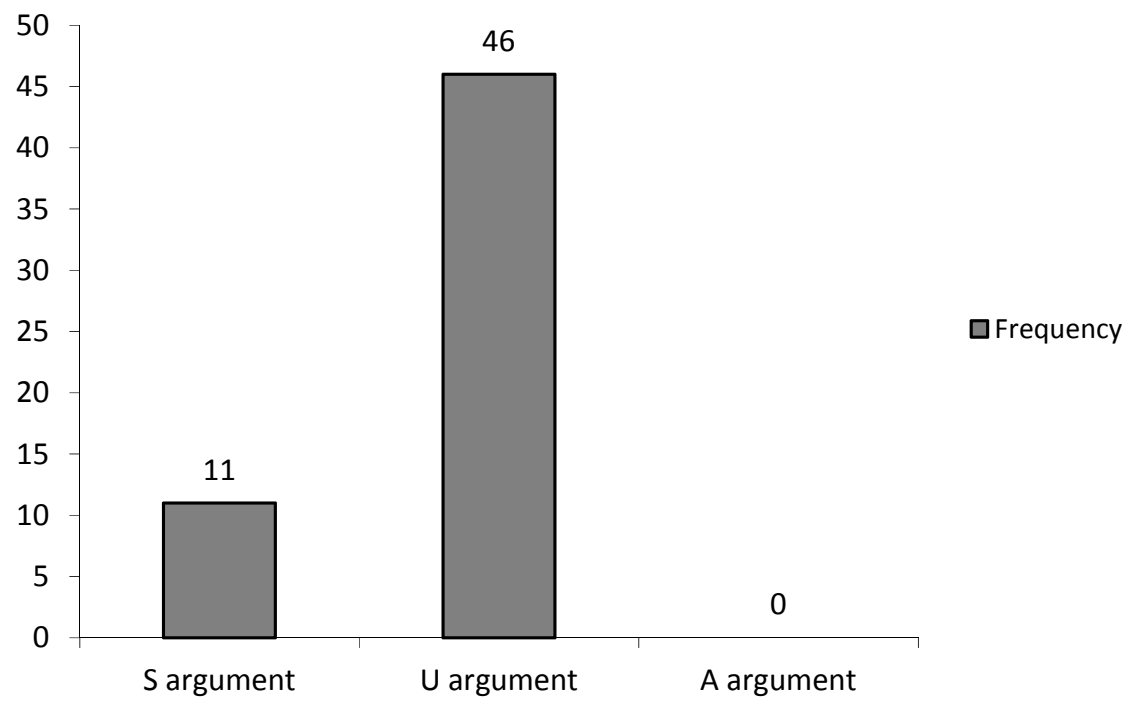

Figure 2: Nominalisations with additional arguments or modifiers (apart from S, U and A)

Figures 1 and 2 show that there are no instances of nominalisations where the actor is expressed without the undergoer being expressed, irrespective of whether there are additional arguments (indirect objects) or modifiers.

The eight remaining instances $(=500-435-57)$ are nominalisations where A and $\mathrm{U}$ are expressed simultaneously. This figure of $1.6 \%(8 / 500)$ is close to Dik's (1985) counts $(1 \%)$ mentioned above; note, however, that the corpus study presented here ignores nominalisations with zero overt arguments (and premodifying arguments).

These figures show that expression of arguments in Dutch nominalisations follows a strictly ergative pattern in the corpus under investigation. To establish whether this is also the case for the marking of arguments, we first have to make clear what is exactly understood by an undergoer. In FDG actor and undergoer are semantic functions (see Hengeveld \& Mackenzie 2008: 194ff.). Undergoers are, prototypically, nonvolitionally affected by the State-of-Affairs. Most direct objects in Dutch are undergoers, but it is not clear whether prepositional objects also qualify as undergoers. One could argue that prepositional objects typically encode arguments with the semantic function of locative. Locative is then to be understood as a prototype, covering instances where the argument is not really spatial in a literal sense. This is the position that FDG takes with regard to recipients/beneficiaries. Still, some predicates can combine alternatively with a direct object and a prepositional object, see (28)-(29). ${ }^{11}$ At first sight, it would seem counterintuitive to assign different semantic functions to these two types of object.

\begin{tabular}{|c|c|c|c|c|}
\hline $\begin{array}{l}Z e \\
\text { they }\end{array}$ & $\begin{array}{l}\text { vertrouwen } \\
\text { trust }\end{array}$ & $\begin{array}{l}(\text { op/in/Ø) } \\
(\text { on/in/Ø) }\end{array}$ & $\begin{array}{l}\text { hun } \\
\text { their }\end{array}$ & $\begin{array}{l}\text { eigen } \\
\text { own }\end{array}$ \\
\hline
\end{tabular}

${ }^{11}$ Apart from the verbs in (28)-(29), there are also verbs which take the applicative prefix bewhen used with a non-prepositional object: kijken naar vs. bekijken. 


$$
\begin{aligned}
& \text { Hij zocht } \quad \text { (naar) de kat. } \\
& \text { he searched } \\
& \text { 'He searched (for) the cat.' }
\end{aligned}
$$

There are two options here. Either the argument hun eigen oordeel is treated as the undergoer, irrespective of the presence of the preposition, or the semantic function shifts when the preposition is used, from undergoer to locative. In line with a functionallydriven form-function approach, the latter position requires there to be (minute) semantic differences between the two constructions. With some verbs, this seems indeed to be the case. In (29), for instance, the prepositional object construction seems to imply that the search is less successful or less focused. Consider the example in (30), where the modifier vruchteloos / een beetje afwezig makes this reading explicit. ${ }^{12}$ In such cases, the direct object construction is less felicitous than the prepositional object construction.

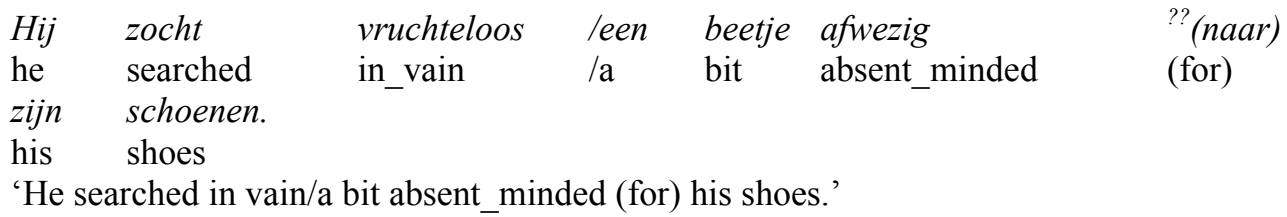

Consequenctly, I treat prepositional objects as non-undergoer (locative) arguments. For the analysis presented here, a distinction will be made between locative arguments, as part of the valency frame of the verb, and locative modifiers, which are optional. The distinction between arguments and modifiers is not easy to maintain theoretically, and will only be used in an operational sense here.

If we treat prepositional objects as locatives, the ergative alignment in the marking of the arguments in Dutch nominalisations remains unaffected. Prepositional objects in nominalisations retain their original preposition and the actor can be accommodated in the possessor slot. In (31), for instance, the verb vertrouwen ('trust') is used, which, as shown in (28), can take a prepositional object with in ('in'), just as in English. ${ }^{13}$ If, on the other hand, the prepositional object in producten met chemische substanties were to be analysed as an undergoer, this example would flout the ergative marking in Dutch nominalisations, as the actor would then take priority over the undergoer in marking by a van adpositional phrase.

het vertrouwen van consumenten in producten met
the trust of consumers in products

${ }^{12}$ The term 'modifier' is used here to gloss over the question whether it is an adverbial modifier or a subject complement in this sentence. Under a traditional analysis vruchteloos would be an adverb and een beetje afwezig would be a subject complement. The decision does not affect the analysis at issue.

${ }^{13}$ Note that vertrouwen is not necessarily productively derived, and may be represented as a ready-made entry in the lexicon. As it is difficult to determine whether or not we are dealing with a true nominalisation - in the case at hand, lexical specialisation cannot convincingly be argued - I have taken a positivist approach, by including every instance of what superficially looked like an instance of nominalisation of the type represented in (4). The only exception is leven ('live/life', as in het leven van Freud, 'the life of Freud'), which has been ignored throughout. 
Straightforward (non-prepositional-object) undergoers always take priority over actors in Dutch nominalisations. This is illustrated in (32)-(33).

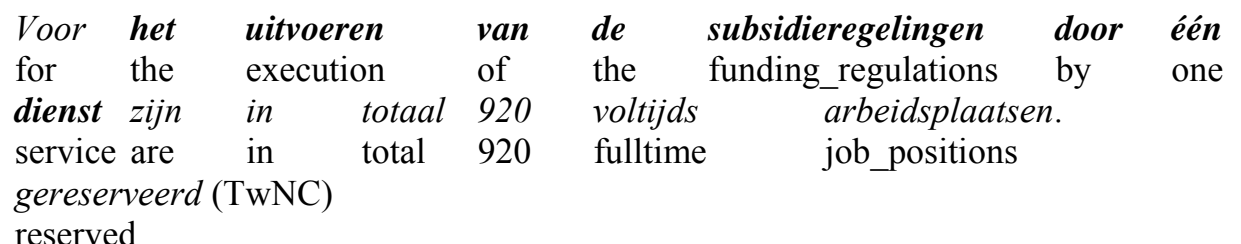

'For the execution of funding arrangements by a single service a total of 920 fulltime positions have been reserved.'

$\begin{array}{llllllll}\text { (...) wie } & \text { het } & \text { gitzwart } & \text { wil zien } & \text { kan } & \text { de } & \text { uitvoering } \\ & \text { who } & \text { it } & \text { pitch-black } & \text { want see } & \text { can } & \text { the } & \text { execution } \\ \text { door de } & \text { Britse } & \text { dirigent } & \text { vergelijken } & \text { met } & \text { het } & \\ \text { by the } & \text { British conductor compare } & \text { to } & \text { the } \\ \text { aantrekken } & \text { van } \text { een nazi-uniform door } & \text { prins } & \text { Harry. (TwNC) } \\ \text { wearing } & \text { of } & \text { a nazi-uniform by } & \text { prince } & \text { Harry }\end{array}$

'If one wants to look at it from a negative perspective, one can compare the execution by the British conductor to prince Harry's wearing of a nazi uniform.'

\section{Explaining the (split-)ergative alignment}

In the previous section it was argued that Dutch nominalisations of the type exemplified in (4) have (split-)ergative alignment, which was confirmed by a corpus study. In the present section, an explanation will be offered for the existence of this ergative tendency in an otherwise accusative language like Dutch. The explanation of the ergative alignment will be sought in discourse motivations, and is thus 'functional' in nature. As such, it is an alternative to a 'formal' explanation like the one given by Alexiadou, who argues that that nominalisations and ergative languages are instantiations of a similar underlying structure, and constitute an unaccusative system with a single theme argument (see Alexiadou 2001: 172-173, 212). From a functional perspective this is not really an 'explanation', but rather a technical reformulation of the observations. While such a formal account may be helpful in making interesting generalizations over different construction types, the claim that both ergative languages and nominalisations have a deficient v ("small v") (Alexiadou 2001: 18, 172) is ultimately a theory-internal argument. analysis?

How then can we account for the (split-)ergative alignment under a functional

Du Bois $(1985,1987)$ gives an interesting explanation for the deeper motivation behind ergativity. In his theory of Preferred Argument Structure, he argues that the ergative alignment is primarily motivated by the discourse-organisational consideration to distinguish given participants from new participants, whereas accusative alignment is motivated by animacy.

Starting from Chafe's insights in the flow of information in discourse, Du Bois observes that in connected discourse, language users rarely use more than one discourse-new, lexical NP. Most predicates, both transitive and intransitive, have either zero or one lexical, discourse-new NP. This is called the "One Lexical Argument 
Constraint" (Du Bois 1987: 819) and the "One New Argument Constraint" (Du Bois 1987: 826). Furthermore, this discourse-new, lexical NP is rarely the A argument, but is nearly always the $\mathrm{S}$ or the $\mathrm{U}(\mathrm{O}$, in Du Bois's terminology) argument. This gives rise to the "Non-lexical A Constraint" (Du Bois 1987: 823) and its pragmatic counterpart, the "Given A Constraint" (Du Bois 1987: 827). The reason for this patterning is that human discourse tends to revolve around human, agentive protagonists. These are likely to have continuative topic status over different sentences and they are more likely to function as A arguments. $U$ arguments, on the other hand, encode more ephemeral, inanimate patients. S arguments, while also likely to encode human, agentive participants, have a high rate of discourse-new referents because of their strategic use in information flow. What happens is that speakers take recourse to an intransitive predicate to verbalise new discourse participants, rather that introducing them in a transitive clause. As Du Bois (1987: 831) puts it: "It appears, then, that speakers often select an intransitive verb, not necessarily for its conceptual content or semantic oneplaceness, but for its compatibility with constraints on information flow." Ergative alignment groups $\mathrm{S}$ and $\mathrm{U}$ together, on the basis of their association with discourse-new elements. It is in these arguments that speakers introduce new participants in the discourse. Accusative alignment on the other hand, is motivated by the fact that $\mathrm{S}$ and $\mathrm{A}$ share other properties. Both are likely to encode human, agentive and topical participants. The association between $\mathrm{S}$ and $\mathrm{U}$ on the basis of their similar behaviour in information flow on the one hand, and the association between $\mathrm{S}$ and $\mathrm{A}$ on the basis of the similarity in the semantics of their referents, constitutes a system of competing motivations. Some languages go with one motivation, while other languages go with the other. Support for this account comes from split-ergative languages. Alignment splits frequently follow the topicality hierarchy (see Siewierska 2004: 149 for this term), such that pronouns and, more generally, agentive participants are more likely to be accusatively aligned. Since such elements are typically discourse-given, and since the distinction between lexical and non-lexical expression is not pertinent here, the association between $\mathrm{S}$ and $\mathrm{A}$ is stronger than the association between $\mathrm{S}$ and $\mathrm{U}$. Accusative alignment is thus more likely to occur when information pressure is low.

Now let's turn to nominalisations. Speakers shape the discourse in order to control the information flow. Introducing new discourse participants is cognitively demanding (Du Bois 1987: 833-834). In transitive clauses, where the undergoer is likely to be discourse-new, its encoding requires quite some processing effort, and as a result, introducing new agentive participants is often relegated to intransitive clauses. In nominalisations, introducing discourse-new participants is difficult as well, as the nominalisation is part of a clause in which either the nominalisation itself or some other argument is discourse-new. The One New Argument Constraint entails that the arguments of the nominalisation themselves should preferably not introduce discoursenew participants. This means that information pressure is even higher in nominalisations than in clauses, which explains why Dutch has an alignment split here: Full clauses have accusative alignment, and nominalisations have ergative alignment. In fact, the functional motivation of high information pressure in nominalisations predicts that there is an implicational universal by which ergativity in main clauses entails ergativity in nominalisations. According to Koptjevskaja-Tamm (1993: 243-244) this is indeed largely the case: While several accusative languages have ergative nominalisations, the opposite hardly occurs. 
This account of the ergative alignment in (Dutch) nominalisations is supported by several other observations.

First, the alignment split between clauses and nominalisations is part of a more general distinction between foreground and background clauses. This distinction is based on Hopper \& Thompson (1980: 280):

"That part of a discourse which does not immediately and crucially contribute to the speaker's goal, but which merely assists, amplifies, or comments on it, is referred to as BACKGROUND. By contrast, the material which supplies the main points of the discourse is known as FOREGROUND."

Subordinate clauses often express backgrounded information, and are often presuppositional in nature. The same is true for nominalisations (Hopper \& Thompson 1980: 285; Noonan 1985: 108; Koptjevskaja-Tamm 1993: 261; Mackenzie 1996: 332). It has been observed that alignment can be split along the foreground-background division. Dixon (1994: 101-104) argues for instance that in languages where relative clauses enter into a split, ergativity is likely to be found in the relative clause. The same is true for other subordinate clauses. ${ }^{14}$

Dutch does not generally split its alignment along the distinction between main clauses and subordinate clauses, but there are a few areas in which we do have such a split, namely in infinitival complements of causative verbs and verba sentiendi and in attributive participles.

While causativised predicates can be construed with accusative alignment, as in (34)-(35), they just as easily take ergative alignment; this is illustrated in (35)-(37), where the $\mathrm{S}$ and $\mathrm{U}$ arguments are zero-marked and the $\mathrm{A}$ argument is introduced by a door adpositional phrase. In fact, the ergative alignment accounts for the vast majority of cases (Dik 1980: 81, cited in Dik 1985).

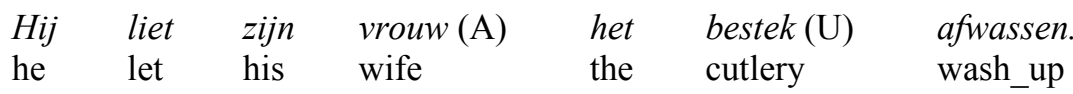

'He let his wife wash up the cutlery.'

$$
\begin{aligned}
& \text { Hij liet het bestek (S) vallen. } \\
& \text { he let the cutlery } \\
& \text { 'He dropped the cutlery.' }
\end{aligned}
$$

$$
\begin{aligned}
& \text { Hij liet het bestek(U) afwassen. } \\
& \text { he let the cutlery wash_up } \\
& \text { 'He ordered the cutlery to be washed up.' }
\end{aligned}
$$

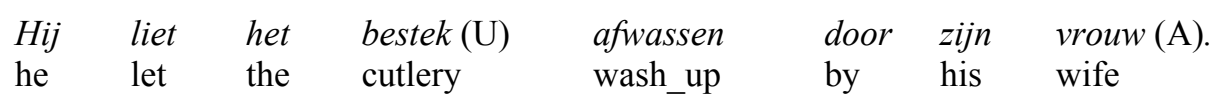

${ }^{14}$ With the exception of purposive clauses, as Dixon notes. In comparison to other types of subordinate clauses, purposive clauses display deviant behaviour with respect to other grammatical phenomena as well, though. Interestingly, this may be due to the lack of presuppositional status (see Verstraete 2008). As the pragmatics of presuppositions belongs to the Contextual Component in FDG, this supports the observation that argument realisation in nominalisations, and more specifically its splitergative alignment in Dutch, is to be dealt with in the Contextual Component, as will be argued in more detail in Section 4. 
'He let his wife wash up the cutlery.'

A similar kind of split can be observed in infinitival complements of verba sentiendi. The accusative alignment in (38) alternates with the ergative alignment in (39). As with the causatives, this requires no passive marking on the verb.

$\begin{array}{lllll}\text { Hij } & \text { hoorde de rechter }(\mathrm{A}) & \text { het } & \text { vonnis }(\mathrm{U}) & \text { voorlezen. } \\ \text { he } & \text { heard the judge } & \text { the } & \text { verdict } & \text { read_out }\end{array}$

'He heard the judge read out the verdict.'

Hij hoorde het vonnis $(\mathrm{U}) \quad \begin{array}{llll}\text { voorlezen door de rechter (A). } \\ \text { he heard the verdict }\end{array}$ read_out by the judge
'He heard the judge read out the verdict.'

Further support for the idea that Dutch has an alignment split along the foregroundbackground dimension can be found in the observation that in attributive past participles, which form another clear case of backgrounding by non-finite verbs, we also find ergative alignment. The noun on which past participles of transitive predicates depend functions as the U, not the A argument of the verb; see (40). Traditionally, this is explained by the 'passive' nature of the past participle. However, rather than with a passive, we are dealing here with ergative alignment, as intransitive past participles can be used attributively as well, see (41). ${ }^{15}$

$\begin{array}{llll}\text { een door holbewoners (A) } & \begin{array}{l}\text { gemaakte } \\ \text { made }\end{array} & \begin{array}{l}\text { grotschildering (U) } \\ \text { cave_painting }\end{array} \\ \text { a by cavemen } & & \end{array}$

$$
\begin{aligned}
& \text { het verdwenen boek (S) } \\
& \text { the disappeared book } \\
& \text { 'the lost book' }
\end{aligned}
$$

Attributive present participles have accusative alignment, as in (42)-(43), but occasionally they occur with ergative alignment as well, as in (42), (44), (45).

een afnemend verschijnsel (S)

'a receding phenomenon'

(43) een vernietigende opmerking (A)

'a devastating remark'

roerende goederen $(\mathrm{U})$

Moving goods

'movables'

$$
\begin{array}{ll}
\text { een stilzwijgende } & \text { voorwaarde }(\mathrm{U}) \\
\text { A concealing } & \text { condition } \\
\text { 'an implicit condition' } &
\end{array}
$$

${ }^{15}$ There is, however, a complication, in that only unaccusative verbs can be used as attributive participles. Unergatives are not possible: *een gezwommen atleet ('a swum athlete'). 
It seems not too far-fetched to attribute the switch to ergative alignment to the increased information flow pressure in all these contexts with additional participants (causatives and verba sentiendi) or backgrounding by deverbalisation (participles).

The interaction between information status and alignment is not restricted to Dutch. Other languages too can have an ergative split along the dimension of information status. In Umpithamu, for instance, ergative case is co-determined by principles of animacy and information structure, with ergative case being used for focal elements (Verstraete 2010). ${ }^{16}$ Consider examples (46)-(48) (from Verstraete 2010: 1638), where the ergative marker -mpal seems to be optional. The presence of the ergative marker is determined by the focality of the NP. In (48), for instance, the ergative marker on nhunha ('other') is due to its contrastive focus function. ${ }^{17}$ The focal value of manta eentinti in (47) is argued in Verstraete (2010: 1643).

$$
\begin{aligned}
& \text { manta eentinti-mpal watyu- } n=i l u w a \\
& \text { child small-ERG spear-PST=3SG.NOM } \\
& \text { 'The child speared it.' }
\end{aligned}
$$

'The child carried it.'

(48) [description of how someone gets a spear ready]
nhunha-mpal watyun=iluwa /Norman
other- ERG spear-PST=3SG.NOM Norman
'Another one speared it, Norman.'

Further support for the discourse motivation of Dutch nominalisations' ergativity comes from the dimensions along which ergativity shows a split here. As said in Section 2, ergative patterning is primarily associated with non-pronominal and postmodifying arguments. What these have in common is that they are syntactically heavier, related to the fact that they tend to be discourse-new. This suggests that the ergative alignment in Dutch nominalisations is crucially related to discourse status considerations.

In the corpus study on 500 nominalisations reported above, an asymmetry is observed in the information status of the undergoer and the actor. Taking definiteness as an approximate indication of given/new status, it becomes clear from Figure 3 that undergoers are more likely to be discourse-new than actors, although the absolute frequency of actors is too small to obtain statistically significant results. ${ }^{18}$

${ }^{16}$ The notion of focality does not completely coincide with that of discourse-new in Verstraete's account. Rather, it has to do with prominence and presupposition, in that "focused items are items that are locally relevant to the development of discourse, and that are set off against a presupposition relating to expectations raised in the immediately preceding clauses" (Verstraete 2010: 1642). Still, both notions have to do with information flow in discourse, thus supporting the line of argumentation here.

17 As an extra-clausal constituent (marked off by a separate intonation contour), Norman is unmarked for case (see Verstraete 2010: 1642).

${ }^{18}$ One may wonder what motivates the introduction of indefinite, discourse-new arguments in nominalisations, given the discourse pressure not to introduce new arguments, discussed above. I return to this question below, in Section 4.3. The short answer is that the indefinite NPs do not really introduce foregrounded participants, but rather co-establish a contextually retrievable State-of-Affairs, often with generic meaning. 


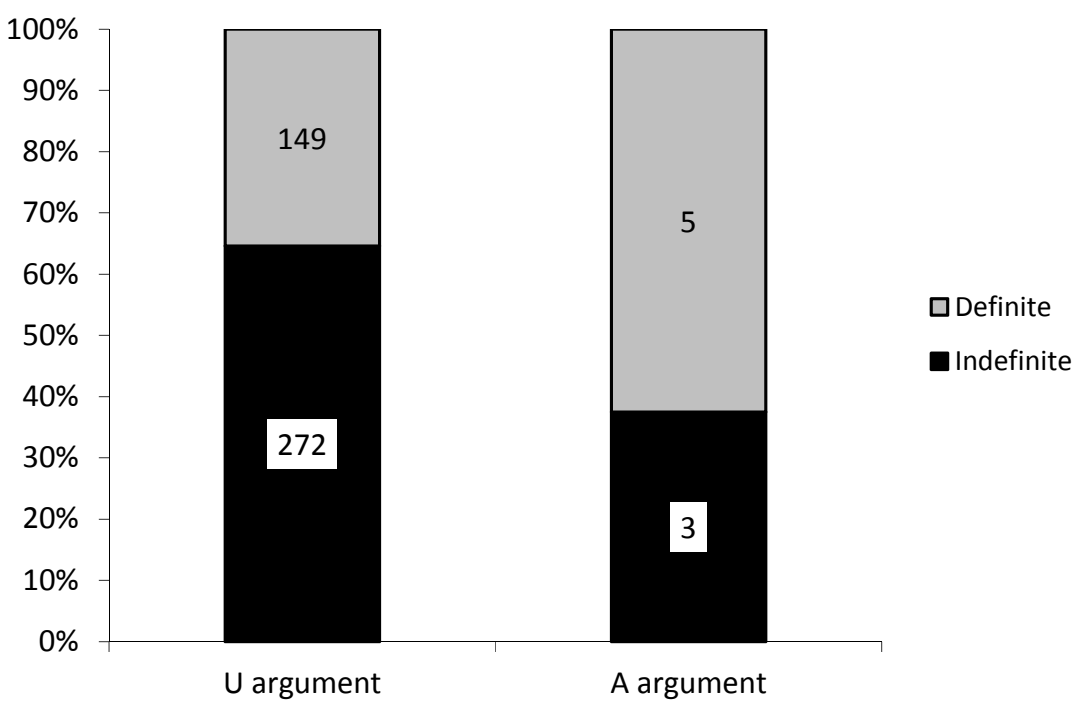

Figure 3: Definiteness of $U$ and A arguments in Dutch nominalisations

If we take a closer look at the attestations where both the actor and the undergoer are expressed, definiteness of the undergoer seems to entail definiteness of the actor. In (49)-(50) both the actor and the undergoer are definite, and in (51)-(52) the actor is definite and the undergoer is indefinite. ${ }^{19}$

$\begin{aligned} & \text { het terugtrekken van de film door producent } \\ & \text { the withdrawal of the film by producer }\end{aligned}$
Westelaken (TwNC)
Westelaken
'Producer Gijs van de Westelaken's withdrawal of the film'

$\begin{array}{llllll}\text { het ontsteken } & \text { van de kaarsjes door de } \\ \text { the lighting } & \text { of the candles } & \text { by the }\end{array}$

delegatieleiders (TwNC)

heads_of_delegation

'the lighting of the candles by the heads of delegation'

het tegenhouden door de senaatsfractie
the stopping of the senate_fraction
van een referendum (TwNC)
of a referendum
'the VVD's senates fraction's stopping of a referendum'

${ }^{19}$ As is clear from these examples, I treat proper names as definite expressions, though not everyone would agree on this. One argument for seeing them as definite is that they are rather awkward in existential there-constructions, which provide a standard test for definiteness (Lyons 1999): 'there appeared John at the bar. What is important here, though, is that a definite undergoer does not co-occur with an indefinite, and thus unidentifiable actor. 


$$
\begin{array}{lllllll}
\text { het } & \text { aantrekken } & \text { van } & \text { een } & \text { nazi-uniform door } & \text { prins Harry (TwNC) } \\
\text { the } & \text { wearing } & \text { of } & \text { a } & \text { nazi-uniform by } & \text { prince Harry }
\end{array}
$$

'prince Harry's wearing of a nazi uniform.'

There is one apparent exception to this tendency: In (53), the undergoer is definite and the actor is indefinite.

het uitvoeren van de $\begin{aligned} & \text { subsidieregelingen } \\ & \text { the execution }\end{aligned}$ of the funding_regulations by ón dienst
(TwNC)

'the execution of funding arrangements by a single service'

However, note that the actor in (53) is a specific indefinite, and if we take into account the context of the example, it becomes clear that the actor is not discourse-new. The 'service' itself was mentioned in the preceding discourse, see (54).

De nieuwe wet, die gevolgen heeft voor ruim zes miljoen huishoudens, harmoniseert een groot aantal subsidieregelingen, zoals voor huur, kinderopvang, zorg en studie. De eerste drie worden vanaf volgend jaar uitbetaald door de belastingdienst, die daarvoor een 'dienst toeslagen' krijgt. De wet moet meer duidelijkheid scheppen voor burgers teneinde het niet gebruikmaken van inkomensafhankelijke regelingen tegen te gaan. Op huursubsidie bijvoorbeeld wordt door 15 tot 27 procent van de mensen die er recht op hebben, geen aanspraak gemaakt. Mensen weten niet dat ze recht hebben op de subsidie of waar ze die moeten aanvragen, ze zien op tegen de papieren rompslomp of schamen zich voor het feit dat ze voor hun inkomen afhankelijk zijn van de overheid. Volgens het kabinet zal door het 'harmoniseren' van de verschillende regelingen de zogenoemde armoedeval worden bestreden, die het voor werklozen onaantrekkelijk maakt om aan het werk te gaan, omdat ze dan hun recht op subsidie verliezen. Voor het uitvoeren van de subsidieregelingen door één dienst zijn in totaal 920 voltijds arbeidsplaatsen gereserveerd, waarvan 150 bij de belastingdienst.

'The new law, which affects over six million households, harmonises a large number of funding arrangements, such as rent, childcare, care and study. The first three are paid from next year on by the tax authorities, who get a 'fees service' for this. The law should provide more clarity for citizens in order to counter the non-use of incomerelated arrangement. Housing grants, for example, are not claimed by 15 to 27 percent of people who are entitled to it. People do not know they are entitled to the grant or where they have to apply for it, or they don't feel like doing the paperwork or they are ashamed of the fact that they depend from the government for their income. According to the government the 'harmonisation' of the various arrangements will counter the socalled poverty trap, which makes it unattractive for the unemployed to get a job as they then lose their right to funding. For the execution of funding arrangements by a single service a total of 920 fulltime positions are reserved, including 150 with the IRS.'

There is another, obvious reason why actors are frequently absent in nominalisations. Often, they are participants in the clause in which the nominalisation plays a role as argument or modifier. Take for instance the example in (55). The actor of the nominalisation (het opruimen ...) is the subject in the main clause (zeven soldaten ...). The same is true in (56) and (57), and examples can easily be multiplied. In fact, more than half of the unexpressed actors are expressed in the matrix clause $(54.7 \%$, see 


\section{Freek Van de Velde}

Figure 4$)^{20}$, and this ignores cases where the referent is retrievable from the broader context or from clauses preceding the matrix clause.


'Yesterday, seven soldiers from a Ukrainian military unit in Iraq were killed when an airplane bomb exploded during the removal of an ammunition depot south of Baghdad.'

$\begin{array}{lllllll}\text { nog } & \text { veel } & \text { sterker is deze pianist in } & \text { het } & \text { creëren } \\ \text { still much } & \text { stronger is } & \text { this pianist in } & \text { the } & \text { creation } \\ \text { van vloeiende } & \text { bewegingen }(\mathrm{TwNC}) & & & & \\ \text { of fluent } & \text { movements } & & & & \end{array}$

$\begin{array}{lllll}\text { Patiënten } & \text { kunnen } & \text { erna problemen krijgen met het } \\ \text { patients } & \text { may } & \text { later problems } & \text { get with the } \\ \text { bewegen } & \text { van de } & \text { schouders. (TwNC) } & & \\ \text { moving } & \text { of the } & & \end{array}$

'Patients may later face problems moving their shoulders'

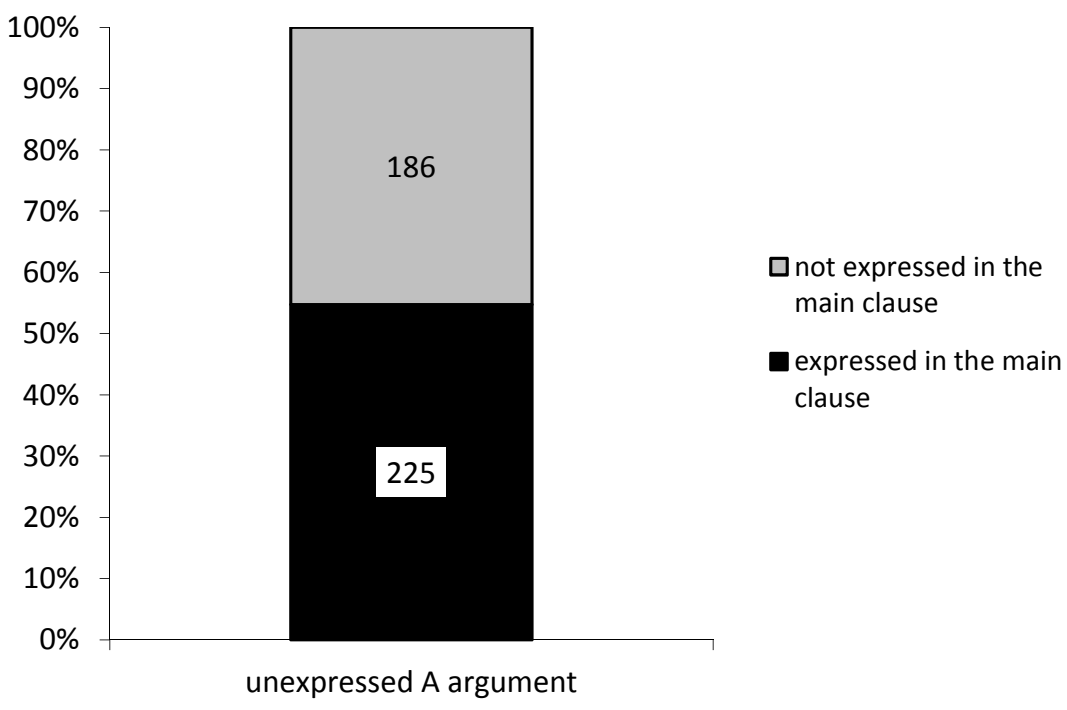

Figure 4: Retrievability of non-expressed A arguments in nominalisations

${ }^{20}$ Two instances with an elliptic matrix clause have been ignored in the counts. 
The absence of actors in nominalisations contrasts with the presence of oblique arguments. While only a limited number of predicates allow prepositional objects (including benefactives/recipients) ${ }^{21}$, they are more common in nominalisations than the actor argument: The sample contains no fewer than 22 examples of oblique arguments (see (58) and (59) for examples, in which the oblique arguments are marked with (L) (for 'Locative', see above)). This is in line with their information status: About half of the instances of oblique arguments are indefinite (10 definites vs. 11 indefinites, plus 1 infinitival realisation). The proportion of indefinite oblique arguments is thus in between the proportion of indefinite undergoers and indefinite actors.

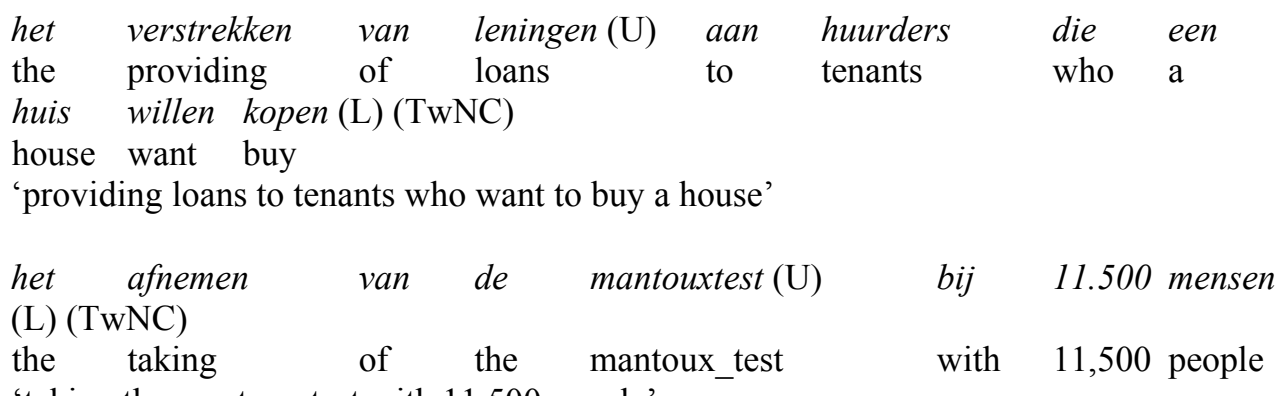

'taking the mantoux test with 11,500 people'

All in all, there are several indications that argument realisation in Dutch nominalisations is crucially determined by information status considerations, as a result of backgrounding. This is not only supported by the actual expression of the arguments ( $\mathrm{S}, \mathrm{U}$ and to a lesser extent $\mathrm{L}$, as opposed to A), but also in the ergative marking by prepositions ( $\mathrm{S}$ and $\mathrm{U}$ in a possessor van adpositional phrase). Additional support comes from the difference in definiteness of the various arguments: Ignoring $\mathrm{S}$, which is less subject to competition with other arguments, indefiniteness in the corpus sample follows a $\mathrm{U}(65 \%$ indefinite $)>\mathrm{L}(52 \%$ indefinite $)>\mathrm{A}$ ( $38 \%$ indefinite) cline - although the low absolute numbers warrant some caution. Also revealing is the observation that other instances of backgrounding, such as attributive participles and infinitival complements, cause an alignment shift from accusative to ergative as well.

\section{Nominalisations: Representation in Functional Discourse Grammar}

In the preceding sections, it has been argued that the exact form of nominalisations in Dutch is determined by discourse considerations. It was shown that the split-ergative alignment of Dutch nominalisations naturally falls out of the discourse status of the arguments. The greater likelihood of undergoers being discourse-new gives them priority over actors in backgrounded states-of-affairs or propositions. The question is how this can be represented in Functional Discourse Grammar (FDG). What component decides whether accusative alignment or ergative alignment is appropriate in a given construction? In this section, it is argued that the Contextual Component plays a crucial role in the encoding of nominalisations. Discourse status, framed in terms of

21 In Dutch nominalisations dative shift is not allowed, so we can treat recipients and benefactives in the same way as prepositional objects. 
'activation', (co-)determines both the use of a nominalisation and its argument realisation.

\subsection{The role of the Contextual Component in the use of nominalisations}

FDG advocates a modularised account of language, in which various components impinge upon the production of linguistic utterances. The actual formulation and encoding of linguistic utterances is handled in the Grammatical Component, but draws also on the essentially non-grammatical Contextual Component as the latter "houses the immediate information received from the Grammatical Component concerning a particular utterance which is relevant to the form that subsequent utterances may take" (Hengeveld \& Mackenzie 2008: 10).

The question is what this kind of information in the Contextual Component precisely is. I would suggest that the Contextual Component is involved with issues having to do with 'activation' (in the sense of Chafe 1994: 53-56). ${ }^{22}$

FDG assumes that the Contextual Component contains information about the discourse status of entities in a written or spoken text. It is important to realise that discourse status is not only attributed to first-order entities (individuals), represented by $\mathrm{x}$ variables at the Representational Level in FDG, but that properties, states-of-affairs, propositions etc. can also be active or inactive in the discourse (see Lambrecht 1994: 74-75). This is clear from cases of anaphoric reference to a State-of-Affairs or proposition, such as (60), where that refers back to the entire State-of-Affairs preceding it. Anaphoric reference crucially depends on what is registered in the Contextual Component at a certain time, and this suggests that such states-of-affairs are represented in the Contextual Component (see Hengeveld \& Mackenzie 2008: 11).

At that point, once the letter is finalised, we then did have a meeting with two members, the Chairman of this Committee that'll be Councillor Park, to just go through it, and that happened on Monday morning of this week (BNC) ${ }^{23}$

Activation of a State-of-Affairs or proposition is not just the result of the unfolding discourse, with what has been mentioned being active and what has not been mentioned being inactive, but it can be actively shaped by the speaker. In (61), for instance, the nominalisation the American attack on the Al-amariyah shelter has not been mentioned in the previous discourse, but the speaker's choice to encode it as a nominalisation, and so to activate it without a proper introduction as a separate proposition, suggests she assumes the hearer to be able to successfully conceive of the State-of-Affairs referred

${ }^{22}$ This means I don't follow Hengeveld \& Mackenzie (this issue) when they see activation as a notion belonging to the Conceptual Component. Their motivation to keep activation (in the Conceptual Component) apart from contextual prominence (in the Contextual Component) is that the former is an individual affair, whereas the latter is shared between the speaker and the hearer. It remains to be seen, however, whether there is a clear boundary between shared vs. private contextual information. Contextual information passes through the Conceptual Component when it impacts Formulation and Encoding (see also Keizer, this issue). Moreover, the literature on activation stresses the joint contribution of speaker and the hearer to the verbal interaction (see below). For the present paper, I'll conflate activation with contextual prominence as used by Hengeveld \& Mackenzie, and I refer to García Velasco (this issue) for a more detailed assessment of the way 'activation' is understood by different scholars.

${ }^{23}$ BNC: British National Corpus, see http://corpus.byu.edu/bnc. 
to, as it is contextually accessible. ${ }^{24}$ In other words, the use of a nominalisation assumes (or sometimes strategically pretends) that the State-of-Affairs is active.

(61) Attempts were made during the war to bomb Saddam's convoy, and the American attack on the Al-Amariyah shelter, which resulted the in the deaths if up to 300 women and children, seems to have been ordered because a high intensity of walkie-talkie traffic was detected at the shelter. (BNC)

Encoding discourse status is thus the result of a negotiation between speaker and hearer:

"Speakers realize, of course, that one or more minds are involved in the communicative use of language. As they speak, they not only take account of the changing activation states of information in their own minds, but also attempt to appreciate parallel changes that are taking place in the minds of their listeners. Language is very much dependent on a speaker's belief about activation states in other minds. Such beliefs themselves constitute an important part of a speaker's ongoing, changing knowledge, and language is adjusted to accord with them. Beliefs about other minds have various sources. To a considerable extent they are based on previous linguistic interaction - on things said within the same discourse, but also on things remembered from previous talk. Others are derived from nonlinguistic interaction, from shared experience, and from shared cultures. Whatever the sources may be, conversation could not function as it does unless speakers took account of activation states in minds beyond their own." (Chafe 1994: 54-55)

Prince (1981: 224) also stresses this speaker-hearer interaction when she defines information packaging as:

"the tailoring of an utterance by a sender to meet the particular assumed needs of the intended receiver. That is, information packaging in natural languages reflects the sender's hypotheses about the receiver's assumptions and believes and strategies."

In a sense nominalisation of a State-of-Affairs or proposition is comparable to marking an NP for definiteness. ${ }^{25}$ Just like definite articles, nominalisations can generate a presuppositional import (Lambrecht 1994: 76), and as such, a nominalisation can be seen as a signal to the hearer that she is supposed to retrieve the referent from what is textually or contextually accessible. ${ }^{26}$ This is even true for some (though certainly not all) indefinite nominalisations. In (62), the indefinite article in the nominalisation an Italian attack on Austria-Hungary signals that the referent is non-identifiable - the reader is not supposed to know that Italy had planned to attack Austria-Hungary - but the concept of an attack has been activated in the preceding discourse. Note that some nominalisations, like (63), strongly favour definite determiners, even when there is no

\footnotetext{
${ }^{24}$ Spelling errors in this example (and other examples in this paper) have not been corrected.

${ }^{25}$ This is not to say that definiteness is the same as activation state of NPs. See García Velasco (this issue) for the relation between identifiability - of which definiteness is the grammatical expression and activation.

${ }^{26}$ Interestingly, some languages have a single marker for definiteness (or more precisely: Identifiability) and nominalisation. Chafe (1994: 153-156) gives examples of Seneca, where the word neh, which compares to the English definite article, can be used to nominalise an event: ne q:sagyędotho ${ }^{2}$ (the I-would-put-wood-in-again, 'to put more wood in'; note that neh is realised as ne in the example).
} 
anaphoric relationship whatsoever. In the Dutch nominalisations that have been investigated in Section 2 and 3, only definite determiners are allowed (*een slachten van dieren 'a slaughtering of animals').

(62) Meanwhile Russia had re-equipped and enlarged her army to an astonishing degree, considering her antiquated and corrupt administrative system. She was now ready to launch a major attack. An Italian attack on Austria-Hungary was also planned. (BNC)

(63) Traveling was dangerous then, as the Yaquis took up the attacking of all the trains in the region. (COCA)

So nominalisations have to do, at least partially, with contextual prominence or activation. And this prominence can be exploited by a speaker. Nominalising a State-ofAffairs gives it a less transient status in the Contextual Component (see also Chafe 1994: 68-69). The effect of using a nominalisation is a greater referential density, hence the high proportion of nominalisations in written genres like academic prose, where processing limits are subservient to information density.

\subsection{The role of the Contextual Component in the argument realisation in nominalisations}

As argued in Section 4.1, the use of nominalisations is driven by considerations that are central to FDG's Contextual Component. They often represent entities that are present in the Contextual Component, either due to prior mention in the discourse, or because they are contextually retrievable. The same is true for the status of arguments of nominalisations. When the argument is a proper name, a pronoun or a definite NP, like e.g. Germany and by the reactionary Junker powers in (64), it is reasonable to assume that the referent is accessible through the Contextual Component, either in the 'Discoursal section', as in the case of Germany, which is anaphorically linked to German people in the preceding discourse, or in the 'Situational (socio-cultural) section', as in the case of the reactionary Junker powers. ${ }^{27}$ But when the argument is an indefinite NP, like e.g. a world-wide network of military bases in (65), the presence of the indefinite article as a marker of unidentifiability makes it implausible that the referent was already activated in the Contextual Component, suggesting that the presence or absence of arguments in nominalisations is more complicated than might be expected at first glance.

(64) The failure of the Prussian and German people to follow the successful example of the French in a revolution from below meant that in 1870 they were forced to accept the unification of Germany by the reactionary Junker powers. (BNC)

(65) The Soviets were already concerned at America's creation of a world-wide network of military bases, her possession of the atomic bomb and her economic strength. (BNC)

How can FDG account for the ergative alignment in Dutch nominalisations?

\footnotetext{
${ }^{27}$ See Connolly (2007, this issue) for these subdivisions in the Contextual Component.
} 
For Dutch a cline can be set up with a decreasing likelihood of accusative alignment and an increasing likelihood of ergative alignment from left to right. In the middle of the cline, language users have a choice for accusative or ergative alignment. The infinitival complements include causative constructions and complements of verba sentiendi (see above). The more 'verbal' the predicate is, the greater the preference for accusative alignment, the more 'nouny' the predicate is, the greater the preference for ergative alignment. The left-hand side of the cline furthermore correlates with foregrounding, while the right-hand side correlates with backgrounding.

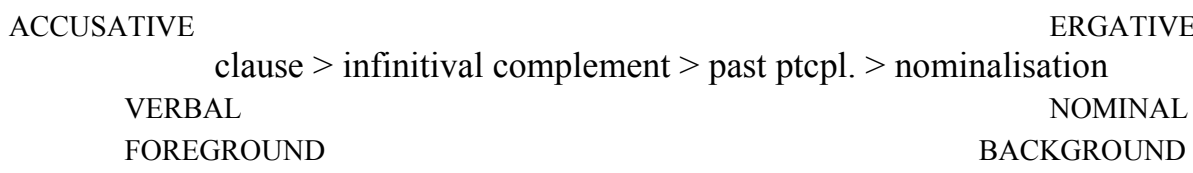

In FDG, alignment is dealt with at the Morphosyntactic Level, but can be sensitive to interpersonal, representational or morphosyntactic factors (see Hengeveld \& Mackenzie 2008: 316ff.). Interpersonally driven alignment occurs when the expression of the morphosyntactic form of the arguments of the predicate is motivated by pragmatic functions, such as topic and focus. Alignment is representationally driven when the argument realisation is defined in terms of semantic functions only, or in case of hierarchical alignment with an inverse marking on the verb when the semantic functions run counter to the animacy hierarchy (see Hengeveld \& Mackenzie 2008: 319-324 for details). Morphosyntactically driven alignment happens in all cases where morphosyntactic organization is not a direct reflection of interpersonal or representational information. This may happen when arguments are expressed differently according to their morphosyntactic complexity.

Alignment is seldom purely interpersonal, representational or morphosyntactic in nature. In Dutch for instance, all levels play a role in the expression of the arguments. The relevance of interpersonal factors can be witnessed in the case of verbs with prepositional objects. Prepositional objects can (but need not) be expressed without their preposition when they have Topic function, formally marked by P1 position. As illustrated in (68), the preposition is then stranded at the end of the clause. In those cases where there is another constituent in $\mathrm{P} 1$, preposition stranding is not possible.

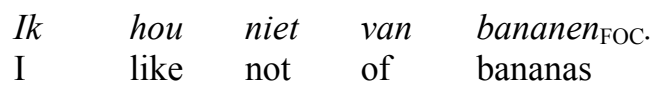
'I do not like bananas.'

$\begin{array}{lllll}\text { Bananen }_{\mathrm{TOP}} \text { hou } & \text { ik } & \text { niet } & \text { van. } \\ \text { bananas like I } & \text { not } & \text { of } \\ \text { 'Bananas I do not like.' } & & & \end{array}$

In other respects, Dutch alignment is sensitive to representational factors. By way of example, consider the argument realisation in the verb gehoorzamen ('obey'). The object can only be made subject through passivisation when the active subject is animate. This is illustrated in examples (69)-(72). Passivisation of (69) into (70) is fine, as both subject and object are animate, but the inanimate subject in (71) precludes passivisation, as shown in (72) (see Van Belle \& Van Langendonck 1996: 229). 


$\begin{array}{llllll}\text { Zijn volgelingen } & \text { gehoorzamen } & \text { hem } & \text { niet } & \text { meer } \\ \text { his } & \text { followers } & \text { obey } & \text { him } & \text { no } & \text { more }\end{array}$

'his followers do not obey him anymore.'

$$
\begin{aligned}
& \text { Hij werd niet meer gehoorzaamd door } \\
& \text { he zijn }
\end{aligned} \begin{aligned}
& \text { volgelingen. } \\
& \text { 'He was not obeyed by his followers anymore.' }
\end{aligned}
$$

$\begin{array}{lllll}\text { Het stuur gehoorzaamde } & \text { hem niet meer. } \\ \text { the wheel obeyed } & \text { him no more }\end{array}$

'He lost control over the wheel'

$\begin{array}{lllllll}{ }^{*} H i j & \text { werd } & \text { niet } & \text { meer gehoorzaamd door het } & \text { stuur. } \\ \text { he } & \text { was no } & \text { longer } & \text { obeyed } & \text { by } & \text { the } & \text { wheel }\end{array}$

Morphosyntactic factors also play a role in the Dutch alignment system. Some verbs require their object to be marked by a preposition when it is realised as an NP, but do not require this when the object is realised as an infinitival complement or as a complement clause, as in (73)-(74), respectively. The difference is due to the syntactic heaviness, rather than to the semantics, as NP realisation of the State-of-Affairs requires the preposition again, see (75). ${ }^{28}$

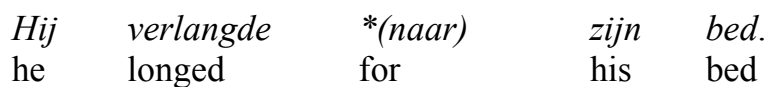

'He longed for his bed.'

$\begin{array}{lllll}\text { Hij verlangde (ernaar) } & \text { weer thuis } & \text { te } & \text { zijn. } \\ \text { he longed } & \text { there_for } & \text { again at_home } & \text { to } & \text { be } \\ \text { 'He longed for it to be home again.' } & & & \end{array}$

$\begin{array}{lll}\text { Hij verlangde * (naar) } & \text { zijn } & \text { thuiskomst. } \\ \text { he longed for } & \text { his home_coming } \\ \text { 'He longed for his return.' } & & \end{array}$

In addition to interpersonal, representational and morphosyntactic factors, alignment can also be motivated, I would suggest, by factors pertaining to the Contextual Component (this is especially the case when there is a choice between different alignment possibilities, as with causatives). If the State-of-Affairs or the Proposition whose alignment is at issue is registered in the Contextual Component, as a result of prior mention in the discourse, this will trigger ergative alignment (or at least increase the chances on ergative alignment). A similar suggestion has been made by Hengeveld \& Mackenzie (2008: 331):

"[T]he actual factors triggering the choice of Subject and Object assignment apply in the Contextual Component, outside the Grammatical Component as such. (...) [T] he key factor to understanding these choices is cohesiveness, which concerns the extent to which referents have already been mentioned in the preceding discourse or can be

${ }^{28}$ Example (75) is grammatical without the preposition, though the meaning of the verb then shifts to 'demand', rather than 'long for'. 
inferred from it. This type of information is stored in the Contextual Component and has to be called upon in the process of morphosyntactic encoding."

The linguistic encoding of a message is carried out by the speaker/writer. The choices she makes necessarily reside in the Conceptual Component. In case of Contextual factors impinging on the encoding, it has to pass through the Conceptual Component (see also Keizer, this issue and García Velasco, this issue). This implies that the Contextual Component does not have a direct impact on the Grammatical Component, but only an indirect impact, through the Conceptual Component. In the next section, the role of the Contextual Component will be fleshed out, by analysing in detail a number of examples from the corpus.

\subsection{The role of the Contextual Component: Examples}

In order to appreciate how both the choice for a nominalisation and the split-ergative alignment call for a full recognition of the role of the Contextual Component and the Conceptual Component in FDG, consider the following nominalisation:

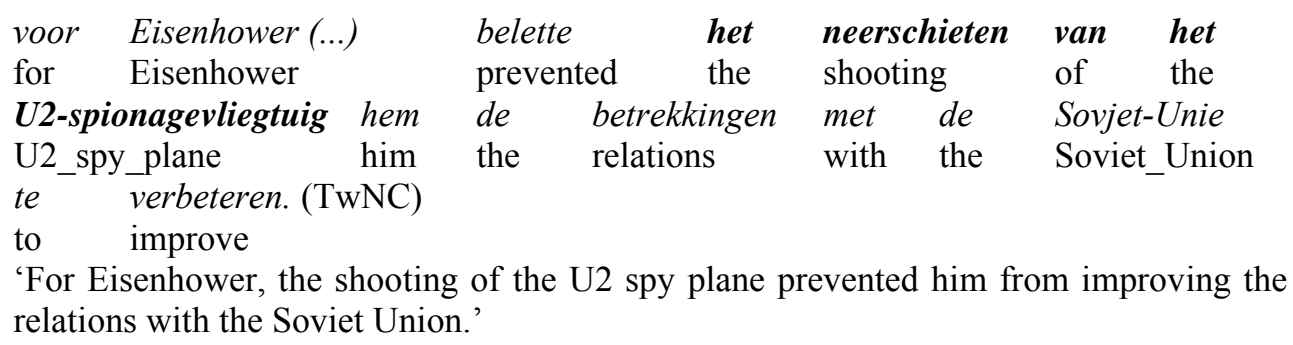

In this example, the nominalisation (in bold) is a State-of-Affairs. The representation in FDG is as follows: ${ }^{29,30}$

(77) IL $\quad \ldots \mathrm{C}_{\mathrm{I}}:\left[\left(\mathrm{R}_{\mathrm{I}}\right.\right.$ :Eisenhower $\left.\left(\mathrm{R}_{\mathrm{I}}\right)\right)\left(+\mathbf{i d} \mathbf{R}_{\mathrm{J}}:\left[\left(\mathbf{T}_{\mathrm{I}}\right)\left(\mathbf{R}_{\mathrm{K}}\right)\right]\left(\mathbf{R}_{\mathrm{J}}\right)\right)\left(\mathrm{T}_{\mathrm{J}}\right)\left(+\mathrm{id} \mathrm{R}_{\mathrm{L}}\right)\left(\mathrm{R}_{\mathrm{M}}:\left[\left(\mathrm{R}_{\mathrm{N}}\right)\left(\mathrm{R}_{\mathrm{O}}\right.\right.\right.$ :the Soviet Union- $\left.\left.\left.\left.\left(\mathrm{R}_{\mathrm{O}}\right)\right)\left(\mathrm{T}_{\mathrm{K}}\right)\right]\left(\mathrm{R}_{\mathrm{M}}\right)\right)\right]\left(\mathrm{C}_{\mathrm{I}}\right) \ldots$

$\operatorname{RL} \quad\left[\left(p_{i}:\left[\left(x_{i}\right)\left(e_{i}:\left(f_{i}:\left[\left(f_{j}\right)\left(e_{j}:\left(f_{k}:\left[\left(f_{i}\right)\left(x_{j}\right)_{U}\right]\left(f_{k}\right)\right)\left(e_{j}\right)_{A}\left(x_{i}\right)_{L}\left(e_{k}:\left(f_{m}:\left[\left(f_{n}\right)\left(-e_{1}-\right.\right.\right.\right.\right.\right.\right.\right.\right.\right.\right.$ )$\left.\left.\left.\left.\left.\left.\left.\left.]\left(\mathrm{f}_{\mathrm{m}}\right)\right)\left(\mathrm{e}_{\mathrm{k}}\right)\right)_{\mathrm{U}}\right]\left(\mathrm{f}_{\mathrm{i}}\right)\right)\left(\mathrm{e}_{\mathrm{i}}\right)\right)\right]\left(\mathrm{p}_{\mathrm{i}}\right)\right)\right]$

ML $\quad \mathrm{Cl}_{\mathrm{i}}:\left[\quad\left(\mathrm{Adp}_{\mathrm{i}}:\left[\left(\mathrm{Pw}_{\mathrm{i}}: \operatorname{voor}\left(\mathrm{Pw}_{\mathrm{i}}\right)\right)\left(\mathrm{Np}_{\mathrm{i}}:\left(\mathrm{Nw}_{\mathrm{i}}:\right.\right.\right.\right.\right.$ Eisenhower $\left.\left.\left.\left.\left(\mathrm{Nw}_{\mathrm{i}}\right)\right)\left(\mathrm{Np}_{\mathrm{i}}\right)\right)\right]\left(\mathrm{Adp}_{\mathrm{i}}\right)\right)$ $\left(\mathrm{Vp}_{\mathrm{i}}:\left(\mathrm{Vw}_{\mathrm{i}}\right.\right.$ : belette $\left.\left.\left(\mathrm{Vw}_{\mathrm{i}}\right)\right)\left(\mathrm{Vp}_{\mathrm{i}}\right)\right)$

$\left(\mathrm{Np}_{\mathbf{j}}\right.$ :

[(Gwi: het $\left.\left(\mathbf{G w}_{\mathrm{i}}\right)\right)$

$\left(V_{w_{j}}:\right.$ neerschieten $\left.\left(V w_{j}\right)\right)$

(Adp $_{\mathrm{j}}$ :

[(Pw $w_{\mathrm{j}}$ : van $\left.\left(\mathbf{P w}_{\mathrm{j}}\right)\right)$

$\left(\mathrm{Np}_{\mathrm{k}}\right.$ :

$\left[\left(\mathbf{G w}_{\mathbf{j}}: \operatorname{het}\left(\mathbf{G w}_{\mathbf{j}}\right)\right)\right.$

\footnotetext{
${ }^{29}$ The adpositional phrase voor Eisenhower is represented as being inside the proposition $\left(\mathrm{p}_{\mathrm{i}}\right)$, but outside the state-of-affairs $\left(\mathrm{e}_{\mathrm{i}}\right)$ at RL.

${ }^{30}$ In this article, I ignore the Episode layer (see Hengeveld \& Mackenzie 2008: 157ff).
} 


\author{
$\left(\mathrm{Nw}_{\mathrm{j}}\right.$ :-U2 spionagevliegtuig- $\left.\left.\left(\mathrm{Nw}_{\mathrm{j}}\right)\right)\right]$ \\ $\left.\left.\left(\mathbf{N} p_{k}\right)\right)\right]$ \\ $\left.\left(\mathrm{Np}_{\mathrm{j}}\right)\right)$ \\ $\left.\left(\mathbf{A d p}_{\mathrm{j}}\right)\right]$ \\ $\left(\mathrm{Np}_{1}:\left(\mathrm{Nw}_{\mathrm{k}}\right.\right.$ : hem $\left.\left.\left(\mathrm{Nw}_{\mathrm{k}}\right)\right)\left(\mathrm{Np}_{\mathrm{l}}\right)\right)$ \\ $\left(\mathrm{Cl}_{\mathrm{j}}\right.$--betrekkingen met de Soviet-Unie te verbeteren- $\left.\left.\left(\mathrm{Cl}_{\mathrm{j}}\right)\right)\right]$ \\ $\left(\mathrm{Cl}_{\mathrm{i}}\right)$
}

The Morphosyntactic expression gets its input from the Interpersonal Level and the Representational Level. There are two State-of-Affairs that function as arguments of the main verb at RL: The State-of-Affairs of 'the shooting of the U2 spy plane' $\left(\mathrm{e}_{\mathrm{j}}\right)$ is the A argument of the verb beletten ('prevent') $\left(\mathrm{f}_{\mathrm{j}}\right)$, and the State-of-Affairs of 'improving the relationships with the Soviet Union' $\left(\mathrm{e}_{\mathrm{k}}\right)$ is the $\mathrm{U}$ argument. The anaphoric personal pronoun hem $\left(\mathrm{x}_{\mathrm{i}}\right)$ is the $\mathrm{L}$ argument. ${ }^{31}$ At the Interpersonal Level, both State-of-Affairs $\left(e_{j}\right)$ and $\left(e_{k}\right)$ are represented by an $R$ variable $\left(R_{J}\right.$ and $R_{M}$, respectively). Executing a Referential Subact $(\mathrm{R})$ for the expression of a State-of-Affairs (e) at the level of Formulation (IL/RL) is a typical situation which leads to a nominalisation (Np) at the level of Encoding (ML/PL) (see Hengeveld 2008), but as can be appreciated in (76), the combination of $\mathrm{R}$ at IL and e at RL does not inevitably trigger a nominalisation: The first State-of-Affairs, the U2 incident, represented by $R_{J}$ and $e_{j}$, is encoded as a noun phrase at ML $\left(\mathrm{Np}_{\mathrm{j}}\right)$, but the second State-of-Affairs, the improvement of the relations with the Soviet Union, represented by $\mathrm{R}_{\mathrm{L}}$ and $\mathrm{e}_{\mathrm{k}}$, is encoded by a non-finite clause $\left(\mathrm{Cl}_{\mathrm{j}}\right)$. This means that the speaker/writer has a choice, and could equally have used the expression dat ze het U2-spionagevliegtuig neergeschoten hadden ('that they had shot the U2 spy plane') and het verbeteren van de relaties met de Sovjet-Unie ('the improvement of the relations with the Soviet Union'). The reason why a nominalisation was chosen over a finite subordinate clause for the encoding of the U2 incident is to be sought in the Contextual Component, and in this case seems to be due to activation/accessibility. The use of the nominalisation suggests that the speaker/writer assumes the addressee to be able to retrieve the designated entity from the Contextual Component. If she had no ground for this assumption, the subordinate clause would have been more appropriate. Indeed, the particular historical event can be assumed to be well-known to the intended audience, but for people who have no recollection of the notorious 1960 event or for people who lack the historical background, the current formulation immediately raises questions as to the specifics of this shooting of the spy plane. ${ }^{32}$ The non-finite clause de betrekkingen met de Sovjet-Unie te verbeteren, on the other hand, is not treated as accessible. Indeed, the improvement of the relations with the Soviet Union is not a specific event, but waxed and waned through time.

Not only the decision whether or not to use a nominalisation is dependent on activation status, but also the expression of arguments in the nominalisation. In example (77), only the $U$ argument of the nominalised verb, het U2-spionagevliegtuig, is expressed $\left(\mathrm{R}_{\mathrm{K}}, \mathrm{x}_{\mathrm{j}}\right)$. The A argument is de Sovjet-Unie, which is activated outside the nominalisation, a common strategy illustrated in (55)-(57). The non-expression of the A argument in the nominalisation alleviates the processing load in the Conceptual

$31\left(-\mathrm{e}_{1^{-}}\right)$is the State-of-Affairs betrekkingen met de Sovjet-Unie. The dashes indicate that the internal structure is not further analysed.

${ }^{32}$ This also explains why this type of nominalisation can only be definite (*een neerschieten van een U2-spionagevliegtuig): If accessibility is the motivation for the use of the nominalisation, it would be strange to express at the same time that it is unidentifiable. 
Component. This can be safely done because 'the Soviet Union' is present in the Contextual Component as a result of the transfer of $\mathrm{R}_{\mathrm{O}}$ to the IL stack in the Contextual Component. When the processing load is not the primary concern, it is of course possible to explicitly mention the A argument, but in that case, an anaphoric modifier (diezelfde, 'the same') can be used, as for instance in (78), which shows that the language user acknowledges the argument's presence in the Contextual Component. ${ }^{33}$ For the example in (76), explicit mention would yield something along the lines of (79)

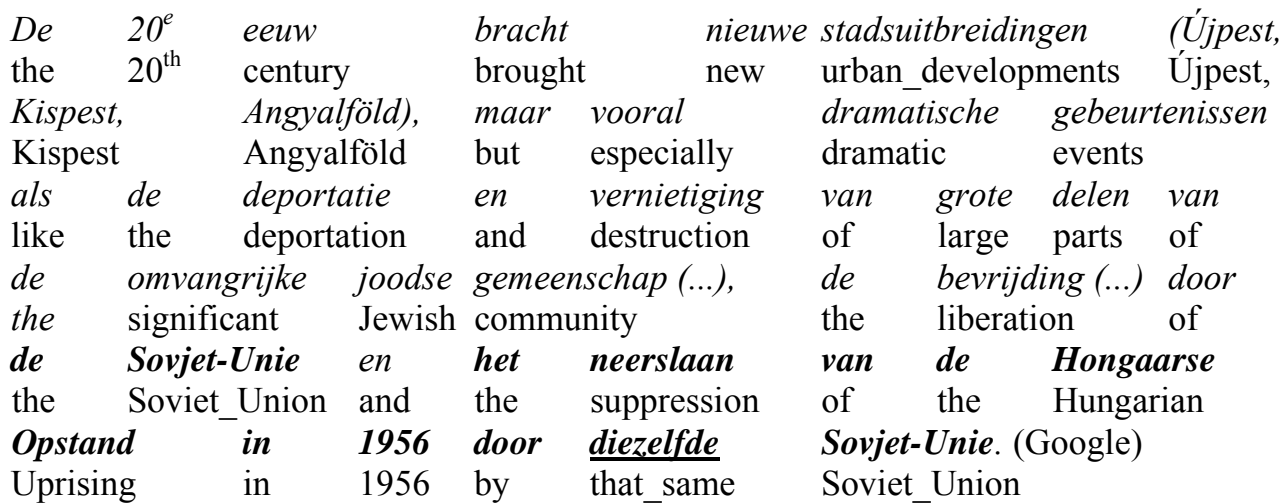

'The 20th century brought new urban developments (Újpest, Kispest, Angyalföld), but in particular dramatic events like the deportation and destruction of large parts of the significant Jewish community (...), the liberation (...) by the Soviet Union and the suppression of the Hungarian Uprising in 1956 by the same Soviet Union.'

\begin{tabular}{llllll} 
voor Eisenhower (...) & \multicolumn{2}{c}{ belette } & het neerschieten van het \\
for Eisenhower & \multicolumn{2}{c}{ prevented the shooting } & of the \\
U2-spionagevliegtuig & door de Sovjet-Unie hem de betrekkingen \\
U2_spy_plane & by the Soviet_Union him the relations \\
met diezelfde & Sovjet-Unie te verbeteren (TwNC) & \\
with that_same & Soviet_Union to improve &
\end{tabular}

'For Eisenhower, the shooting of the U2 spy plane by the Soviet Union prevented him from improving the relations with that same Soviet Union.'

Not all instances of nominalisations can be explained by the fact that they are readily available in the Contextual Component on the basis of prior mention in the ongoing discourse or on the basis of their presence as specific events in the long-term memory (such as the U2-incident in (76)). There is another reason why the speaker/writer may opt for a nominalisation. This can be illustrated by the example in (80).

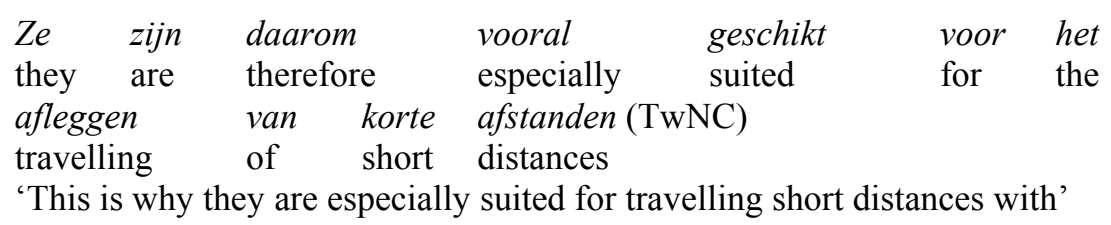

${ }^{33}$ Actually, the use of the heavy anaphor diezelfde is also motivated by the contrast between bevrijden en neerslaan, both performed by the same agent. 


\section{Freek Van de Velde}

In this example, the nominalisation het afleggen van korte afstanden is a Configurational Property that functions as an argument of the (Lexical) Property geschikt. This can be represented by the semantic function of Reference (Ref) at the Representational Level. The full representation at the Interpersonal Level (from the rank of the Communicated Content down), the Representational Level and the Morphosyntactic Level in the Grammatical Component is given in (81). ${ }^{34,35}$ The nominalisation is again represented in bold.

IL $\quad \ldots C_{\mathrm{I}}:\left[\left(+\mathrm{id} \mathrm{R}_{\mathrm{I}}\right)\left(\mathrm{T}_{\mathrm{I}}\right)\left(\mathbf{R}_{\mathrm{J}}:\left[\left(\mathbf{T}_{\mathrm{J}}\right)\left(\mathbf{R}_{\mathbf{K}}\right)\right]\left(\mathbf{R}_{\mathrm{J}}\right)\right)\left(+\mathrm{id} \mathrm{R}_{\mathrm{L}}\right)\right]\left(\mathrm{C}_{\mathrm{I}}\right) \ldots$

RL $\quad\left(\mathrm{p}_{\mathrm{i}}:\left(\mathrm{e}_{\mathrm{i}}:\left(\mathrm{f}_{\mathrm{i}}:\left[\left(\mathrm{x}_{\mathrm{i}}\right)\left[\left(\mathrm{f}_{\mathrm{j}}:\right.\right.\right.\right.\right.\right.$ geschikt $\left.\left(\mathrm{f}_{\mathrm{j}}\right)\right):\left(\mathbf{f}_{\mathrm{k}}:\left[\left(\mathbf{f}_{\mathrm{l}}: \operatorname{afleggen}\left(\mathbf{f}_{\mathrm{i}}\right)\right)\left(\mathbf{m x}_{\mathrm{j}}:\right.\right.\right.$-korte

afstand $\left.\left.\left.\left.\left.\left.\left.\left(\mathbf{x}_{\mathbf{j}}\right)\right)_{\mathbf{U}} \mathbf{l}\left(\mathbf{f}_{\mathrm{k}}\right)\right]_{\text {Ref }}\right)\right]\left(\mathrm{f}_{\mathrm{i}}\right)\right)\left(\mathrm{e}_{\mathrm{i}}\right):\left(\mathrm{r}_{\mathrm{i}}\right)\left(\mathrm{e}_{\mathrm{i}}\right)\right)\left(\mathrm{p}_{\mathrm{i}}\right)\right)$

ML



The nominalisation is a Referential Subact $\left(\mathrm{R}_{\mathrm{J}}\right)$ at the Interpersonal Level and a Configurational Property at the Representational Level $\left(f_{k}\right)$. As said with regard to example (76), this in itself is not enough to trigger the nominalisation $\left(\mathrm{Np}_{\mathrm{j}}\right)$ at the Morphosyntactic Level. In principle, the speaker/writer could also have opted for a realisation like om korte afstanden af te leggen, a tenseless infinitival clause which can serve perfectly well as the realisation of a Configurational Property (or a State-ofAffairs, see also (76)). The motivation to opt for the nominalisation in (80) cannot reside in the Grammatical Component, but has to come from the Contextual Component. By encoding the Configurational Property as a definite Noun phrase, it is more backgrounded than in its infinitival realisation. The definite article signals identifiability. Identifiability is often the result of a referent being present in the Contextual Component, but in the case at hand, this is not plausible. In the preceding discourse, the travelling of short distances has not been mentioned. How do we end up then with a morphosyntactic expression that suggests the presence of the property in the

\footnotetext{
${ }^{34}$ For the representation of daarom by $\mathrm{R}_{\mathrm{L}}$ at IL, $\mathrm{r}_{\mathrm{i}}$ at $\mathrm{RL}$ and $\left(\operatorname{Advp}_{\mathrm{i}}\right.$ :-daarom- $\left.\left(\operatorname{Advp}_{\mathrm{i}}\right)\right)$ at $\mathrm{ML}$, see Hengeveld \& Mackenzie (2008: 272).

${ }^{35}$ The $\mathrm{x}_{\mathrm{j}}$ argument of the nominalisation has not been analysed at RL in its constituents. A more spelled-out representation would look like: $\left(\mathrm{m} \mathrm{x}_{\mathrm{j}}\right.$ : $\left[\left(\mathrm{f}_{\mathrm{m}}\right.\right.$ : afstand $\left.\left.\left(\mathrm{f}_{\mathrm{m}}\right)\right)\left(\mathrm{x}_{\mathrm{j}}\right)\right]$ : $\left(\mathrm{f}_{\mathrm{n}}\right.$ : $\left.\left.\operatorname{kort}\left(\mathrm{f}_{\mathrm{n}}\right)\right)\left(\mathrm{x}_{\mathrm{j}}\right)\right)$.
} 
Contextual Component? The reason is that we are dealing with a generic meaning here. ${ }^{36}$ Generic NPs often have the definite article, see (82). Genericity can be represented as an operator at RL. In (80) the generic operator belongs to the Configurational Property $\left(\mathrm{f}_{\mathrm{k}}\right)$.

\section{The desert tortoise is a herbivore (Google)}

If genericity is indeed what triggers the (definite) nominalisation het afleggen van korte afstanden, rather than the infinitival clause om korte afstanden af te leggen, then it should be impossible to add an adverbial referring to a specific time or place. This is indeed the case: Adding such adverbials is less felicitous with the nominalisation than with the infinitival clause.

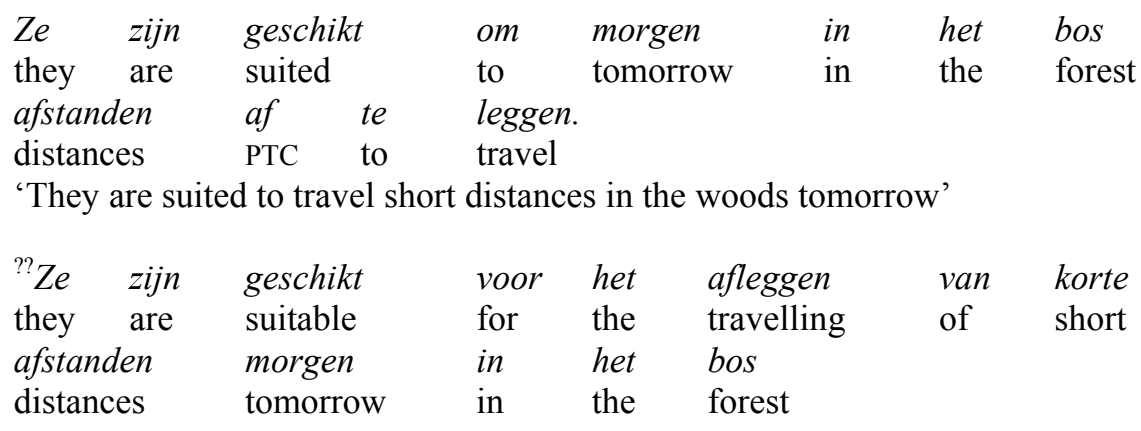

To summarise, both in the case of the Configurational Property nominalisation in (80) and in the case of the State-of-Affairs nominalisation in (76) the expression at the Morphosyntactic form is at least partially the result of what happens in the Contextual Component. The particular status of the Contextual Component also co-determines what the argument realisation of the nominalisation will be. Both the choice for an encoding strategy in the form of a nominalisation and its argument realisation is taken in the Conceptual Component, and passed on to Formulation in the Grammatical Component.

Nominalisations can be considered as instructions to the addressee to retrieve the Proposition, the State-of-Affairs, the Configurational Property from the Contextual Component. This links up with the presuppositional nature of many nominalisations. Rather than feeding the Contextual Component with new referents, the addressee is thus required to scan the Contextual Component - where both prior mentions and more longterm encyclopedic knowledge is stored. As nominalisations can be quite complex, with nominalisations functioning as dependents of other nominalisations, as for instance in (85) and (86), and often have to be processed compositionally, as in (87), where there are multiple modifiers in the nominalisations, the full expression of all the arguments can make the construction unwieldy. The speaker/writer is aiming for quick access, rather than independent assertion of the nominalised proposition or State-of-Affairs. The increased pressure on the expression of arguments and modifiers leads to expression of the most newsworthy participants only. This is best achieved by ergative alignment, for reasons explained in Du Bois (1987). Retrieval of the non-expressed,

\footnotetext{
${ }^{36}$ See Heyvaert (2008) for the role of genericity in the construction of gerundive nominalisations in English (which do, however, constitute a different type of nominalisation than the type treated in this article).
} 
given participants is accommodated in the Contextual Component (see Connolly 2007: 26-28).

$\begin{array}{llllll}\text { Enerzijds } & \text { biedt } & \text { het } & \text { kansen } & \text { voor andere sporten, } \\ \text { on_the_one_hand } & \text { offers } & \text { the } & \text { chances } & \text { for other sports } \\ \text { anderzijds } & \text { kan het } & \text { wegvallen } & \text { van reclame-inkomsten } \\ \text { on_the_other_hand can the } & \text { loss } & \text { of advertising_revenue } \\ \text { door het verdwijnen van } & \text { voetbal } & \text { leiden tot een korter } \\ \text { by the disappearance of } & \text { football } & \text { lead to a shorter } \\ \text { programme } & & & & & \\ \text { programma } & & & & \\ \text { (TwNC) } & & & & \end{array}$

'On the one hand it offers opportunities for other sports, on the other hand, the loss of advertising revenue through the loss of football may lead to a shorter programme.'

\begin{tabular}{|c|c|c|c|c|c|c|c|c|}
\hline $\begin{array}{l}\text { Een } \\
\mathrm{A}\end{array}$ & $\begin{array}{l}\text { waarschuwin } \\
\text { warning syst }\end{array}$ & $\begin{array}{l}\text { ssysteem (...) } \\
\text { n }\end{array}$ & $\begin{array}{l}\text { is } \\
\text { is }\end{array}$ & $\begin{array}{l}\text { niet } \\
\text { not }\end{array}$ & $\begin{array}{l}\text { alleen } \\
\text { only }\end{array}$ & $\begin{array}{l}\text { een } \\
\mathrm{a}\end{array}$ & $\begin{array}{l}\text { kwestie } \\
\text { matter }\end{array}$ & \\
\hline & $\begin{array}{l}\text { technologie, } \\
\text { technology }\end{array}$ & $\begin{array}{ll}\text { maar } & \text { ook } \\
\text { but } & \text { also }\end{array}$ & $\begin{array}{l}\text { van } \\
\text { of }\end{array}$ & $\begin{array}{l}\text { het } \\
\text { the }\end{array}$ & $\begin{array}{l}\text { nemen } \\
\text { taking }\end{array}$ & $\begin{array}{l}\text { van } \\
\text { of }\end{array}$ & $\begin{array}{l}\text { de } \\
\text { the }\end{array}$ & $\begin{array}{l}\text { juiste } \\
\text { correct }\end{array}$ \\
\hline $\begin{array}{l}\text { acties } \\
\text { actions }\end{array}$ & $\begin{array}{ll}\text { ná } & \text { het } \\
\text { after } & \text { the }\end{array}$ & $\begin{array}{l}\text { waarnemen } \\
\text { observing }\end{array}$ & $\begin{array}{l}\text { van } \\
\text { of }\end{array}$ & $\begin{array}{l}\text { een } \\
\mathrm{a}\end{array}$ & $\begin{array}{l}\text { tsunam } \\
\text { tsunam }\end{array}$ & mi (TwNC & C) & \\
\hline
\end{tabular}

\begin{tabular}{|c|c|c|c|c|c|c|c|c|c|}
\hline $\begin{array}{c}\text { Justitie } \\
\text { Justice }\end{array}$ & $\begin{array}{l}\text { verc } \\
\text { susp }\end{array}$ & & $\begin{array}{l}d e \\
\text { the }\end{array}$ & $\begin{array}{l}\text { man } \\
\text { man }\end{array}$ & $\begin{array}{l}\text { er } \\
\text { there }\end{array}$ & $\begin{array}{l}\text { ook } \\
\text { also }\end{array}$ & $\begin{array}{l}\text { van } \\
\text { of }\end{array}$ & $\begin{array}{l}\text { voorc } \\
\text { sible }\end{array}$ & \\
\hline te & $z i j n$ & voor & het & smokk & elen & van & ruim & 10 & kilo \\
\hline to & be & for & the & smugg & & of & more than & 10 & kilo \\
\hline cocaïne & & in & mei & 2003 & onder & een & deklāing & van & vis \\
\hline cocain & & van & May & 2003 & under & $\mathrm{a}$ & deck_cargo & of & fish \\
\hline $\begin{array}{l}\text { vanuit } \\
\text { from }\end{array}$ & & $\begin{array}{l}\text { Surin } \\
\text { Surin }\end{array}$ & & $\begin{array}{l}\text { naar } \\
\text { to }\end{array}$ & $\begin{array}{l}\text { Neder } \\
\text { the N }\end{array}$ & $\begin{array}{l}\text { Ind. } \\
\text { herl }\end{array}$ & $\begin{array}{l}\text { wNC) } \\
\text { ls }\end{array}$ & & \\
\hline
\end{tabular}

'Justice suspects the man was also responsible for smuggling over 10 kilograms of cocaine in May 2003 under a deck cargo of fish from Surinam to the Netherlands.'

\section{Conclusions}

In this paper it has been argued that Dutch nominalisations of the type het eten van vlees (lit. 'the eating of meat') have split-ergative alignment both in the expression and the formal marking of their arguments. The switch to ergative alignment in an otherwise accusative language can be explained by the backgrounding function of nominalisations, the information flow in the arguments and the presuppositional import. It has also been shown that in other areas of its syntax, ergative alignment crops up in Dutch for similar reasons. Finally, it has been argued that in order to account for the morphosyntactic expression of nominalisations in FDG the Contextual Component must be recognised to play a crucial role. 


\section{References}

Alexiadou, A. (2001) Functional structure in nominals. Nominalization and ergativity. Amsterdam: John Benjamins Publishing Company.

Chafe, W. (1994) Discourse, consciousness, and time. The flow and displacement of conscious experience in speaking and writing. Chicago: University of Chicago Press.

Connolly, J.H. (2007) Context in Functional Discourse Grammar. Alfa 51/2: 11-33.

Dik, S.C. (1980) Studies in Functional Grammar. London: Academic Press.

Dik, S.C. (1985) Nederlandse nominalisaties in een funktionele grammatika. Forum der Letteren 26: 82107.

Dixon, R.M.W. (1994) Ergativity. Cambridge: Cambridge University Press.

Du Bois, J.W. (1985) Competing motivations. In J. Haiman (ed.), Iconicity in syntax. Amsterdam: John Benjamins Publishing Company, pp. 343-365.

Du Bois, J.W. (1987) The discourse basis of ergativity. Language 63: 805-855.

Gundel, J., N. Hedberg, and R. Zacharski (1993) Cognitive status and the form of referring expressions in discourse. Language 69.2: 175-204.

Haeseryn, W., K. Romijn, G. Geerts, J. de Rooij, and M.C. van den Toorn (1997) Algemene Nederlandse spraakkunst. $2^{\text {nd }}$ ed. Groningen: Martinus Nijhoff.

Harbert, W. (2007) The Germanic languages. Cambridge: Cambridge University Press.

Hengeveld, K. (2008) Prototypical and non-prototypical noun phrases in Functional Discourse Grammar. In D. García Velasco, and J. Rijkhoff (eds.), The noun phrase in Functional Discourse Grammar. Berlin: Mouton de Gruyter, pp. 43-62.

Hengeveld, K., and J.L. Mackenzie (2008) Functional Discourse Grammar. A typologically-based theory of language structure. Oxford: Oxford University Press.

Hengeveld, K., and J.L. Mackenzie (2010) Functional Discourse Grammar. In B. Heine, and H. Narrog (eds.), The Oxford Handbook of Linguistic Analysis. Oxford: Oxford University Press, pp. 367-400.

Heyvaert, L. (2008) On the constructional semantics of gerundive nominalizations. Folia Linguistica 42.1: $39-82$.

Hopper, P.J., and S.A. Thompson (1980) Transitivity in grammar and discourse. Language 56.2: 251-299.

Keizer, E. (2004) Term structure in FG: A modest proposal. Working Papers in Functional Grammar 78.

Koptjevskaja-Tamm, M. (1993) Nominalizations. London: Routledge.

Koptjevskaja-Tamm, M. (2003) Action nominal constructions in the languages of Europe. In F. Plank (ed.), Noun phrase structure in the languages of Europe. Berlin: Mouton de Gruyter, pp. 723-759.

Lambrecht, K. (1994) Information structure and sentence form. Topic, focus, and the mental representations of discourse referents. Cambridge: Cambridge University Press.

Lyons, C. (1999) Definiteness. Cambridge: Cambridge University Press. 
Mackenzie, J.L. (1985) Nominalization and valency reduction. In A.M. Bolkestein, C. de Groot, and J.L. Mackenzie (eds.), Predicates and terms in functional grammar. Dordrecht: Foris, pp. 29-47.

Mackenzie, J.L. (1996) English nominalizations in the layered model of the sentence. In B. Devriendt, L. Goossens, and J. van der Auwera (eds.), Complex structures. A functionalist perspective. Berlin: Mouton de Gruyter, pp. 325-355.

Noonan, M. (1985) 'Complementation’. In T. Shopen (ed.), Language typology and syntactic description. Volume II. Complex constructions. Cambridge: Cambridge University Press.

Prince, E. (1981) Towards a taxonomy of given-new information. In P. Cole (ed.), Radical pragmatics. New York: Academic Press, pp. 223-255.

Ross, J.R. (1973) Nouniness. In O. Fujimura (ed.), Three dimensions of linguistics theory. Tokyo: TEC $137-257$.

Siewierska, A. (2004) Person. Cambridge: Cambridge University Press.

Silverstein, M. (1986) Hierarchy of features and ergativity. In P. Muysken, and H. van Riemsdijk (eds.), Features and projections. Dordrecht: Foris, pp. 163-232. Originally published in R.M.W. Dixon (ed.), 1976. Grammatical Categories in Australian Languages. Canberra: Australian Institutes of Aboriginal Studies, pp. 112-171.

Van Belle, W., and W. Van Langendonck (1996) The indirect object in Dutch. In W. Van Belle, and W. Van Langendonck (eds.), The Dative. Volume 1: Descriptive studies. Amsterdam: John Benjamins Publishing Company, pp. 217-250.

Verstraete, J.-C. (2008) The status of purpose, reason, and intended endpoint in the typology of complex sentences: Implications for layered models of clause structure. Linguistics 46.4: 757-788.

Verstraete, J.-C. (2010) Animacy and information structure in the system of ergative marking in Umpithamu. Lingua 120: 1637-1651.

FREEK VAN DE VELDE, Ph.D., is a postdoctoral research fellow with the FWO Research Foundation at the University of Leuven, Belgium. His research is situated in the domain of Dutch and West Germanic morphosyntax, both synchronically and diachronically, and theoretical models of grammar language change. His Ph.D. dealt with the history of the noun phrase.

Address: Department of linguistics, University of Leuven, Blijde Inkomststraat 21, P.O. Box 3308, Leuven BE-3000. E-mail: freek.vandevelde@arts.kuleuven.be. 